\title{
Postmodern Dönemde Siyasal Alanın Yapısal Dönüșümü ve Postmodern Siyasi Liderlik
}

\author{
Süleyman Güven'
}

\begin{abstract}
Öz
Bu çalışmanın amacı, postmodern olarak tanımlanan geç modern dönemde siyasal alanın yeniden yapılanışı ve siyasi liderlerin yeni niteliklerinin dayandığı temelleri ele almaktır. Bu çerçevede, postmodern siyasal alanının modern dönem siyasal alanından farklı olduğu, postmodern dönem siyasetinin temel kavramlarından birinin "esneklik" kavramı olduğu, postmodern siyasal alanda ve bu alanın aktörleri olan siyasi liderlerde esnekliğin hakim olduğu ve siyasal karar alma süreçlerinin de esneklik üzerine kurulduğu çalışmanın varsayımını oluşturmaktadır. Çalışmada yöntem olarak literatür taraması seçilmiştir. İlgili literatür taranarak temel siyasal yapının değişimi ve dönüşümü öncelikle ele alınmıştır. Ardından bu dönüşümün postmodern siyasete ve postmodern siyasi liderin özelliklerine nasıl yansıdığı açıklanmaya çalışıımıştır. Bu amaçla, çalışmada modern döneme hakim olan siyasal yapı ile postmodern döneme egemen olan siyasal yapı ele alınıp tartışılmıştır. Sonuç olarak çalışma, postmodern dönemde siyasal alanda meydana gelen dönüşüm ile postmodern siyasi liderin nitelikleri arasında anlamlı bir uyumun olduğu değerlendirmesine ulaşmıştır.
\end{abstract}

Anahtar Kelimeler: Modern Siyasal Alan, Postmodern Siyasal Alan, Liderlik, Modern Siyasi Liderlik, Postmodern Siyasi Liderlik, Esneklik

\section{The Structural Transformation of The Political Sphere In The Postmodern Period and The Postmodern Political Leadership}

\begin{abstract}
The aim of this study is to examine the reconfiguration of the political sphere and to discuss fundamentals of the new characteristics of political leaders in the postmodern period. In this context, the assumption of the study is that postmodern political sphere is different from the modern political sphere; that one of the basic characteristic notions of the postmodern policy is "flexibility"; that political resolution process is based on flexibility and postmodern politicians' acts in a flexibility field. Literature review has been selected as the method of the study. The related literature has been reviewed and the change and transformation of the basic political structure have been considered on a preferential basis. Then, the study tries to explain the effects of this transformation on the postmodern politics and postmodern political leaders' characteristics. With that purpose, modern and postmodern political structures have been discussed in detail
\end{abstract}


in the study. In conclusion, the study has reached the assessment that there is a significant correlation between the characteristics of postmodern political leaders' and transformation of the political sphere in the postmodern period.

Keywords: Modern Political Sphere, Postmodern Political Sphere, Leadership, Modern Politic Leadership, Postmodern Politic Leadership, Flexibility. 


\section{Giriș}

$\mathrm{T}$ oplumsal hayatta yaşanan değişim ve dönüşümlerde siyasal alanın belirleyiciliği önemli bir yer tutmaktadır. Siyasal alan toplumda ve toplumsal alanda meydana gelen değişim ve dönüşümlerde önemli bir etken olarak yer alırken aynı zamanda kendisi de toplumda meydana gelen değişim ve dönüşümlerden etkilenmektedir. $\mathrm{Bu}$ çerçevede siyasal alanın üzerine kurulduğu genel yapı önem kazanmaktadır. $\mathrm{Bu}$ yapı seçmen tercihinin şekillenmesinde önemli bir rol oynadığı gibi seçmen tercihlerine göre politika geliştirme eğilimi içerisinde olan postmodern siyasi liderlerin de biçimlenmesinde önemli bir işlev görmektedir. Bu çerçevede siyaset ve siyasetin söyleminin dayandığı temellerin araştırılması, postmodern dönemin yapı çözümüne bir katkı sağlamak açısından önem arz etmektedir. Bu noktada araştırılması gereken postmodern dönemin siyasal alandaki yapısını ele almak, bu döneme eleştirel bir açıdan bakmak ve bu dönemin hâkim siyasal yapısını tanımlamaktır. Postmodern dönem siyasal alanı, modern dönem siyasal alanından farklı bir yapı içerisindedir. Modern dönemde siyaset, ulus devlet sınırları içerisinde toplumsal sınıfların ve ideolojilerin iktidar mücadelesi şeklinde sürdürülürken postmodern olarak tanımlanan geç modern dönemde modern dönemin siyasal yapılarının sınırları muğlaklaşmış, sınırlar arasında geçişgenlikler ortaya çıkmaya başlamıştır. Bununla birlikte bu dönemde siyasal alan küreselleşerek nitelik değiştirmiş, iktidar mücadelesi devletsel sınırların dışına çıkmıştır. Burada belirleyici güç olarak akışkan bir yapıda yer alan küresel sermaye ortaya çıkmış ve devletlerin egemenlik sınırlarını aşan bir şekilde önemli bir aktör haline gelmiştir. Toplumsal sınıflarda da refah devleti uygulamalarının etkisiyle keskin ayrımlar ortadan kalkmış ve sınıf temelli bakış açısı siyasal alandaki belirleyiciliğini önemli oranda yitirmiştir. Sınıf temelli bakış açısının zayıflamasıyla yeni toplumsal hareketler de yeni bir eylemlilik mantığı içerisinde ortaya çıkmaya başlamışlardır. Bu dönemde birer üst anlatı olarak ideolojiler de iktidar mücadelesinden geri çekilmişlerdir.

Postmodern dönemde siyasal alanda yaşanan bu değişimler siyasal hayatın vazgeçilmez unsuru olan siyasal liderliğe de yansımıştır. Kısaca denilebilir ki postmodern siyaset, liderlik tarzını da etkilemiştir. Modern lider, modern siyasal yapının bir gereği olarak her şeyden önce ideoloji bağımlı bir niteliğe sahiptir. Bununla birlikte modern lider katı ilişkiler çerçevesinde dikey bir iletişim tarzını benimseyen, hiyerarşik bir yapıda tanımlanmış sınırlar içerisinde vizyoner bir özne konumundadır. Buna karşılık postmodern lider ideolojiye daha az bağımlı, esnek ilişkiler çerçevesinde yatay iletişimi ön plana çıkaran, an'a odaklı pasif bir özne niteliği taşımaktadır.

Çalışmada modernite - postmodernite ayırımının yapılması ve bu çerçevede postmodernite kavramının kullanımı moderniteden her alanda kesin kopuşları ifade etmek amacıyla değil; geç modern dönemi isimlendirmek ve bu çerçevede siyasal alanda meydana gelen değişimleri tanımlamada pratik bir işlev görmesi içindir. Modernite ile postmoderniteyi kesin çizgilerle birbirinden ayırmanın zorluğu ortadadır. Bu iki kavramın ifade ettiği yapılar arasında birbiriyle bağlantılı ve iç içe geçmiş alanlar olduğu gibi kavramların ifade ettiği yapıların birbirinden farklılaştığı ve ayrıştıkları noktalar da mevcuttur. Bu çerçevede çalışma, merkezine aldığı postmodern dönem siyasal alan kavramının geç modern dönemde moderniteden her alanda kesin çizgilerle ayrıldığını iddia etmemektedir. Bununla beraber modernitede sınırları belli siyasal alanların/yapıların postmodern dönem tanımlaması içerisinde aynı yapısal formları ile işlev görmedikleri ve belli bir değişim ve dönüşüm içerisinde sınırlarının aşındığını 
kabul etmektedir. Bu nedenle, postmodern dönem tanımlaması içerisinde siyasal alanın yeniden yapılanışı ve buna bağlı olarak siyasi liderin bu yapı içerisinde taşımış olduğu özelliklerinin neler olduğunun ortaya konulması amaçlanmıştır. Çalışmada, postmodern dönem siyasal alanının modern dönem siyasal alanından yapısal olarak farklılaştığı, modern dönemde yer alan katılıkların yerini esnekliklerin aldığını ve bu çerçevede postmodern siyasette ve siyasetçide katılığa yer olmadığı ortaya konulmaya çalışılacaktır. Bu amaçla ilgili literatür taranarak postmodern siyasetin ve siyasi liderin niteliklerinin alt yapısını oluşturan temel yapılar öncelikle ele alınacak, ardından bu yapıların postmodern siyasete ve postmodern siyasi liderin özelliklerine nasıl yansıdığı açıklanmaya çalışılacaktır. Öncelikle modern ve postmodern dönem siyasal alanı incelenecek, ardından liderlik ve postmodern dönem siyasi liderlik kavramları ele alınacaktır.

\section{Modern Siyasal Alan}

Postmodern dönemde siyasal alanda yaşanılan yapısal dönüşümün ortaya konulabilmesi için öncelikle postmodern dönemin öncülü olan modern dönem siyasal yapısının ana belirleyenlerinin neler olduğunun ortaya konulması gerekmektedir. Bu açıdan modern dönemin siyasal yapısına kısaca bakmakta fayda vardır. Modernite, modern toplumun gelişimine paralel olarak geleneksel düzenin karşıtı; ekonomik ve idari rasyonalizasyonun, çizgisel ilerlemenin ve sosyal dünyanın farklılaşmasının vuku bulduğu bir durumu ifade eder. Moderniteyi yaşayan bir toplum; bilimsel ve teknolojik alanlarda ilerleme, toplumsal sınıflar, ideolojiler, ulus devlet şeklinde örgütlenme ve bu örgütsel yapısıyla dünya kapitalist sisteminde yer alma, endüstrileşme, şehirleşme metalaşmanın hızla yaygınlaşması, mekanikleşme, değişim ve piyasa ile karakterize olur (Sarıbay, 2001: 4-5; Kellner, 2000: 371). Buradan hareketle modern dönemin siyaset ve iktidar anlayışının, modern dönemin toplumsal, ekonomik ve kültürel yapısına uygun bir şekil aldığı ifade edilebilir. Bu dönemde özellikle Batı'da siyasal hayatın işleyişini tanzim eden belli başlı bazı temel yapılardan bahsetmek mümkündür. Bu yapılardan ilki sınıf çıkarlarını önceleyen toplumsal kesimler ve hareketler ile bu sınıf ve hareketlere karşı reaksiyonlardan oluşan sınıfsal bir toplum ve iş hayatıdır. İkinci olarak modern siyasal alan değer yüklü olan ve toplumsal yaşamın hemen hemen her alanını düzenleme iddiasında olan ideolojiler tarafından ele alınabilir. Üçüncü ve son olarak modern siyasal alanın en önemli unsurlarından biri olan ve belirlenmiş sınırları içinde kural koyma ve uygulama egemenliğine sahip olduğunu iddia eden ulus devletler tarafından tanımlanabilir.

Yukarıda da ifade edildiği gibi Batı'da endüstri devrimiyle ortaya çıkan ve dönemin ekonomik yapısı içerisinde gittikçe örgütlü hale gelen sınıfsal yapı modern siyasal alanın önemli bir belirleyeni olmuştur. Bu dönemde Batı feodal yapısı tarafından belirlenen toplumsal ilişkilerin oluşturduğu toplumsal yapı değişmiş ve yerini temelde emekçi/ işçi sınıfı ve burjuva/şehirli zengin sınıf olmak üzere iki sınıflı bir toplumsal düzenin ortaya çıktığı ve adına "modern toplum" denilen yeni bir toplumsal yapıya bırakmıştır. Bu toplumsal yapı içerisinde bireyselleşme giderek artmış, topluluklar arasındaki ilişki biçimleri rasyonellik ve fonksiyonellik etrafında yeniden yapılanmış, örgütler ve örgütsel yapılar ise giderek uzmanlaşmışlardır. Bu toplumsal yapı içerisinde farklı ekonomik sınıfları temsil eden ve kendilerini temsil ettikleri sınıf çıkarlarıyla özdeşleştiren siyasal partiler ortaya çıktığı gibi ekonomik temelli toplumsal sınıflardan bağımsız ama ideoloji ve değer yüklü siyasal hareketler de ortaya çıkmıştır. 
$\mathrm{Bu}$ dönemde siyasal partiler ve toplumsal hareketler modern dönem siyasetinin başat aktörleri olmuşlardır. Modern dönem siyasal partileri hem ekonomik sınıf temelli ideolojiler tarafından biçimlenmişlerdir hem de herhangi bir toplumsal sınıfın çıkarlarına odaklanmayan; ancak, toplumu bir bütün olarak dönüştürmeye çalışan ideolojilerce şekillenmişlerdir. Batı siyasal hayatında din ve dini kurumlar eski etkinliklerini kaybetmişlerse de bunların yerine ideolojiler değer üretici konum elde ederek onların bırakmış olduğu boşluğu doldurmaya yönelmişlerdir. Bu durum Batı'nın devlet düzeyinde laikleşmesi, toplumsal düzeyde ise sekülerleşmesi aşamasında bir ara durak, bir aşama işlevi de görmüştür. Bu dönem ideolojileri dini referanslardan arındırılmış bir değer üreterek toplumun dini alanla olan ilişkisini sorunlu hale getirmişlerdir. Modern dönemde siyasetin en önemli belirleyenlerinden biri olan ideoloji, Daniel Bell tarafından basit bir kültürel dünya görüşü veya bir menfaat maskesi olmak yerine; fikirleri ihtirasla kaynaştıran, tarihsel olarak konumlandırılmış, fikirleri sosyal kaldıraçlara dönüştürmeye çalışan ve fikirleri dönüştürürken insanları da dönüştüren bir inanç sistemi olarak tanımlanmaktadır. Bell'e göre ideoloji, vurucu bir güç haline geldiğinde, dünyaya gözleri tamamen kapalı bir şekilde bakan ve sorulacak herhangi bir soruya hazır cevaplar üreten kapalı bir sistemdir (2013: 11). Bu çerçevede ideoloji kavramı modern dönemde ortaya çıkan siyasal akım ve düşüncelerin tanımlanması ve anlaşılmasında anahtar rol oynayan önemli kavramlardan bir tanesidir denilebilir. Çünkü bu dönemde ortaya çıkan siyasal akım ve hareketler genellikle belli bir ideoloji ile kendilerini tanımlamışlar ve bu ideolojiye uygun bir dünya tasavvur etmişlerdir. Ortaya çıkan siyasal hareketlere hem teorik hem de pratik bir alan açmada bir araç olarak da kullanılan ideolojiler, takipçilerine daha iyi bir gelecek vaadinde bulunmuşlar ve belli bir sistematik içinde tutarlı olma çabası içine girmişlerdir.

Modern dönemde Batı siyasal hayatının işleyişini belirleyen temel yapılardan bir diğer yapı ise ulus devlet yapısıdır. Bu dönemde ulus devlet, kapitalist üretim tarzının hem bir aracı hem de onun dışa açılan itici gücüdür. Modern dönemde önplana çıkan bir devlet şekli olarak ulus devletin temel yapısı onsekizinci yüzyılda belirmeye başlamıştır. Charles Tilly, 1800 'den önce Avrupa'da çeşitli zamanlarda pek çok devlet biçiminin varolduğunu; ancak, 18. yüzyıldan itibaren artık belli bir devlet biçiminin hâkim olmaya başladığını belirtmektedir. Buna göre, çok boyutlu süreç ve mekanizmalarla oluşturulan ve devam ettirilmeye çalışılan ulus-devlet birbirinden farklılaşan, heterojen büyük bölgeleri ve geniş alanları homojen bir yapı etrafında bütünleştirmeye ve bu çerçevede bütün vatandaşlarına üniter bir sistemi uygulama iddiasında olan bir devlet yapılanmasıdır (1995: 61). Bu üniter devlet aynı zamanda kendi ülkesel sınırları içerisinde sahip olduğunu iddia ettiği egemenlik haklarını herhangi bir şekilde başka bir kimseyle paylaşmak istemeyen ve güçlü bir özne olma iddiasında olan bir devlettir. Ulus devlet, iç egemenliğini öncelikle ülkesel sınırları aracılığıyla diğer devletlerden ayırmakta, herhangi bir dış unsurun müdahalesine kapalı hale getirmekte ve egemenlik hakları açısından kendisini diğer devletlerle eşitlemektedir. Bununla birlikte, bu devlet, uyruğu altında bulunan kişilerden kendisine her koşulda itaat edilmesi ve gerektiğinde cebir unsurunu da kullanarak politikalarına uyulması doğrultusunda hak ve yetkilere sahip olduğunu iddia etmiştir. Ulus devlette bu hak ve yetki, sadece uyruklarına uygulanmamış ülkesel sınırları dahilinde bulunan ve faaliyet gösteren her türlü unsuru kapsayacak şekilde geniş tutulmuştur. Bu çerçevede ulus devlet, her türlü bilgi, mal, para, sermaye kaynakları ve insan unsuru üzerinde denetim ve düzenleme yoluna gitmiştir. 


\section{Postmodern Siyasal Alan}

Jameson (2005), Featherstone (2005) ve Lyotard (1994) gibi postmoderniteyi savunan yazarların ifade ettiği biçimde, postmodernizm, İkinci Dünya Savaşı sonrasında Batı toplumlarının eski yerleşik sosyal ilişkilerinin çözüldüğü ve daha karmaşık, iç içe geçmiş sosyal gruplar ağına dönüştüğü ayırt edici bir toplumsal değişme aşamasına geçtiği düşüncesini ön plana çıkaran yeni ve geniş bir yaklaşımlar bohçasıdır (Yanıklar, 2010: 210). Bu çerçevede, Featherstone'un ifade ettiği gibi, "postmodernlikten söz etmek, kendine özgü örgütleyici ilkelere sahip yeni bir toplumsal totalitenin ortaya çıkışını içeren bir çağ değişikliğini ya da modernlikten kopuşu ileri sürmek anlamına gelir" (Featherstone, 2005: 22). Bu çağ değişikliği aynı zamanda sosyal, siyasal, kültürel ve ekonomik alanlarda bir farklılaşmayı ve içinde bulunduğumuz dönemin öncülünden niteliksel olarak farklı olduğunu ifade eder (Yanıklar, 2010: 210). Geç modern dönemi tanımlamak, sanayi sonrası toplumu ifade etmek ve Batı toplumlarını anlatmak için kullanılan postmodern kavramı, sadece sınaî üretim ve teknolojik gelişme ile sınırlı bir örgütlenme biçimine göndermede bulunmamakta, aynı zamanda modern toplumun bireyinden farklı bir birey ve toplum anlayışını, farklı bir kültürel yapıyı ve nihayet farklı bir siyaset ve iktidar anlayışını da içermektedir (Örs, 2009: 8). Bu açıdan bakıldığında postmodern dönem siyasal alanı yeni temeller üzerinden yapılanmştır. Bu temeller modern dönem siyasal yapılanmasına da yansıyarak siyasal alanın yapısal bir değişim ve dönüşüm geçirmesini beraberinde getirmiştir.

Her ne kadar modern dönemden keskin çizgilerle ayrılamasa da ve kimi toplumlarda birarada yaşansa da postmodern dönem olarak ifade edilen geç modern döneme gelindiğinde yukarıda ifade edilen sınıf, ideoloji ve ulus devlet gibi belli bir bütünlük oluşturan yapılar aşınmış, bir çok alanda görülen parçalanmışlık postmodern veya geç modern dönem siyasetinin işleyişinde önemli bir belirleyen olmaya başlamıştır. Bu dönemde ekonomik temelli toplumsal sınıflar siyasal alandaki ağırlıklarını kaybederken yeni toplumsal hareketler ortaya çıkmıştır. İdeolojiler de reddedilmeye veya keskin bir belirleyen olmaktan çıkmaya başlamıştır. Ulus-devlet ise küresel kapitalizmin sınırları aşan niteliği tarafından aşındırılmıştır. Bu dönemin işleyişini belirleyen yapılar 1960'ı yıllardan itibaren özellikle Batı'da klasik modern değerlerden farklı yeni değerler ve bu değerler çerçevesinde oluşmaya başlayan toplumsal hareketler tarafından belirlenmeye başlanmıştır. Bu belirlenim yeni bir siyasal alan ve siyasal eylemlilik anlayışı tartışmalarının da ortaya çıkmasına neden olmuştur. Bu çerçevede öncelikle postmodern bir siyasal anlayışı doğuran ve bu dönemde modern siyasal yapının aşınmasını ve değişmesini tetikleyen en önemli unsurlardan birisi Batı'da yaşanan ekonomik ve sosyal durgunluğun da etkisiyle ortaya çıkan ve kendilerini öteki olarak tanımlayan yeni sosyal ve toplumsal hareketler ile bu hareketlerin hızlandırdığı yeni siyasi anlayışlardır. Buradaki önemli husus bu yeni toplumsal hareketlerin klasik modern sınıf konularını işlememesi, sınıf yapılarını önemsememesi ve sınıfsal ayrıcalıkları ortaya çıkarmasıdır. Bu dönemde ortaya çıkan toplumsal hareketlerin karakteri ve bu hareketlerin sorunsallaştırdıkları toplumsal problemler klasik sınıf terimleriyle açıklanabilecek nitelikte değildir. Bu dönemde ortaya atılan ve çözümlenmeye çalışılan problemler daha çok özel nitelikli ve daha dar kapsamlı denebilecek toplumsal cinsiyet, etnisite, sosyal haklar ve yaşa dayalı ayırımlar olmuştur. Yeni sosyal ve toplumsal hareketler de bu problemler çerçevesinde oluşmaya başlamış ve bu sorunları kimliklerinin bir parçası haline getirmeye çalışmışlardır. 
Bu yeni toplumsal hareketlerin özelliklerine yakından bakıldığında modern dönemdeki toplumsal hareketlerden ve sınıflardan yapısal olarak oldukça farklı oldukları görülmektedir. Öncelikle yeni toplumsal hareketlerin, modern toplumsal hareketler ve onları temsil eden siyasal partilerdeki gibi sistemli ve bütünlüklü bir örgüt ve yönetim yapıları yoktur. Bu hareketler belli bir merkezden yoksun, yerel nitelikli, parçalı ve düzensiz bir yapıdadırlar. Modern toplumsal ve siyasal hareketlerin uzun dönemli stratejileri ve planlarına karşılık postmodern toplumsal yapıların ve bunların yansıması olan siyasal hareketlerin kısa dönemli ve plansız bir hareket tarzları vardır.

Modern dönemde varolan toplumsal yapının geç modern dönemde değişime uğraması modern dönemde siyasetin temel belirleyicilerinden biri olan toplumsal sınıfların siyasal süreçlerde belirleyici olma özelliğinin zayıflaması sonucunu doğurmuştur. Toplumsal/ sınıfsal yapının değişimi genel olarak siyasal yapıdan ve siyasal kararlardan bağımsız değildir. Özellikle 1929 ekonomik buhranından sonra gündeme getirilen ve tüm kapitalist ülkelerde uygulanmaya çalışılan refah devleti ${ }^{2}$ politikaları toplumsal değişimde önemli bir rol oynamıştır. Refah devleti uygulamalarının üzerinde yoğunlaştığı ve toplumsal sınıflar arasındaki keskin ayırımların ortadan kalkmasına hizmet eden işlevleri sosyal güvenlik ve sosyal adaleti devlet eliyle yerine getirme yönündeki uygulamalarıdır. Bu çerçevede sosyal içerikli harcamalar sürekli artmış, toplumsal/sınıfsal çatışmalar hızlı bir azalma eğilimi göstermiş ve sağlık, eğitim ve çalışma koşullarının iyileştirilmesi yönünde kapsamlı değişiklikler yapılmıştır. Bu dönemde vergiler artan oranlı hale getirilmiş, bu yolla kamu hizmetleri ve transferleri -gelirin yeniden paylaşımı- mümkün hale gelmiştir. Sağlık hizmetleri herkese ücretsiz tıbbi bakım sağlar hale getirilmiş, devlet çapında sosyal yardım, işsizlik ödeneği, özürlülere yardım ve emeklilik sistemleri ücret dışı cömert gelirler sağlamaya başlamıştır. Bütün kapitalist devletler tam istihdam, sosyal güvenlik ve eşitlikçi amaçlara yönelik siyasal eylemler içerisine girmişlerdir. Bu dönem boyunca tüm gelişmiş ülkeler refah amaçlarını yerine getirirken, kapitalist ulusal ekonomilerinin yaşamsallığını da tehlikeye atmamışlardır. (Scharpf, 1999: 2-3; Akt: Özdemir, 2005: 700-701) Bu durum 1970'li yıllara kadar devam etmiştir. Ancak 1970'li yıllarda refah devleti uygulamalarının aşırı maliyetli olmaya başlaması refah devletinin bir kriz sarmalına girmesi sonucunu doğurmuştur. Bu dönemde ortaya çıkan ekonomik durgunluk ve işsizlik refah devleti uygulamalarının da ciddi bir şekilde sorgulanmasını beraberinde getirmiştir. Bu sorgulamalarla birlikte refah devletinin sosyal haklarla ilgili uygulamaları 1980'li yıllardan itibaren izlenmeye başlanan Neo-liberal politikalarda sosyal devlet anlayışı adı altında etkisini devam ettirerek sınıf temelli kutuplaşmaların azalmasına hizmet etmiştir. Bu uygulamalar, tarihsel süreç içerisinde geleneksel sağ ve sol eğilimli partiler arasında sosyo-ekonomik ve politik uygulamalar bakımından keskin farkların ortadan kalkmasına hizmet ederek siyasetin işleyişinde sınıf temelli bakış açılarının marjinalize olmasında önemli bir işlev görmüştür.

Siyasette yeni unsurların önplana çıkması ve modern dönemin belirleyici unsurlarının siyasal süreçte gerilemesinin önemli bir nedeni de postmodern dönemde ideolojilere karşı yaklaşımlarda yaşanan değişimdir. Bu dönemde ideolojiler önemli oranda gözden düşmüş, siyasal sürecin ve karar alma mekanizmalarının işleyişindeki belirleyicilik niteliklerinden giderek uzaklaşmışlardır. Postmodern dönem siyasal hayatında ideolojik

2 Modern anlamıyla refah devleti (Welfare State) kavramı, sosyal refahın maksimizasyonu amacıyla devletin ekonomiye aktif ve kapsamlı müdahalelerde bulunmasını öngören bir anlayışı temsil etmektedir. Bu model, piyasa ekonomisinin başarısızıklarını ve yetersizliklerini ortadan kaldırma amacını gütmekte ve müdahaleci, düzenleyici, yeniden dağıtıcı ve girişimci bir devlet anlayışını ifade etmektedir.( Alp, 2009: 266) 
belirlenimin azalması postmodernist yazarlarca postmodern durumun bir özelliği olarak ifade edilmektedir (Lyotard, 1994: 88) Lyotard'a göre postmodernizmde büyük anlatılar yerini küçük anlatılara bırakmakta, her şeyi açıklama iddiasında olan büyük teoriler, meta anlatılar sorgulanmaktadır. Yine Lyotard'a göre postmodernite meta anlatılara yönelik inanmazlıktır ve bu inanmazlık bilimlerdeki [positivist anlayıșta] ilerlemenin bir ürünüdür (Lyotard, 1994: 88). Buna göre postmodernitede büyük anlatılar reddedilerek bunun yerine küçük anlatılara öncelik verilmektedir. Bu çerçevede postmodernizm meta/büyük anlatı olarak tanımladığı ideolojileri, dinleri vb. kapsayıcı yapıları/anlatıları eleştirerek herkesin öznel deneyimine dayalı anlatıların daha iyi olduğunu öne sürerek farklıı̆ğa ve izafiliğe vurgu yapmaktadır. Büyük anlatılar kapsayıcı dünya görüşlerine sahip olmaları ve belli bir sistem dahilinde işlemeyi öngörmeleri nedeniyle postmodern bir yapıda ve dünyada bu mümkün değildir. Meta veya üst anlatılar, problemler karşısında her zaman kendi açılarından bir çözüm sunabilme potansiyeli ile hareket etmelerinden dolayı eleştiriye tabi tutulmaktadırlar. Postmodernist anlayışa göre bu üst anlatıların öznel deneyimlerden üstün olduğunu ortaya koyabilecek kanıtlar yoktur. Kapitalizm, sosyalizm gibi ekonomik sistemler, Marksizm ve Liberalizm gibi beşeri kaynaklı siyasal sistemler ile beşeri ve ilahi kaynaklı dinler ${ }^{3}$ arasında herhangi bir farkılık olmadığı gibi bunların bir diğerinden daha üstün veya değerli olduklarına dair herhangi bir neden de yoktur. Bu yaklaşım düşünce ve inançta tutarlılığı mantıksız hale getirmekte, değer yönelimli üst anlatıları değer yönelimli olmayan hikaye veya anlatılarla aynı seviyeye indirerek değersizleştirmeye çalışmaktadır. Postmodernist anlayışın bu girişimi kurumsal ve kalıcı yapılarla pejoratif ve geçici oluşumlar arasında geçişgenlikleri, muğlaklığı ve esnekliği doğal hale getirmektedir. Bu çerçeveden bakıldığında modernizm ve postmodernizm arasındaki farklıığı ortaya koymada esneklik kavramı ayırıcı bir rol oynamaktadır.

Esneklik kavramı, postmodern anlamda hareketliliğe, sürekli değişime, şekilsizliğe, güvensizliğe, bağsızlığa ve istikrarsızlığa göndermede bulunmaktadır. Postmodern dönem siyasal alanında uygulanan politikaların çok sık değişmesi, esneklik uygulamalarını da sıklıkla gündeme getirmiştir. Esneklikle beraber yaşanan hızlı değişim; belirsizlik, beklentisizlik, kuralsızlık, tutarsızlık ve ölçüsüzlüğü yapılandırarak, insan yaşamını düzenleyip istikrar sağlayan, insanın genel yaşam alanını etkileyen siyasal alanı ve toplumsal ilişkileri sağlamlaştıran ilkeleri yerinden ederek insanı sağlam bir zeminden yoksun bırakmaktadır (Şentürk, 2010: 122-123). Esneklik uygulamalarıyla birlikte postmodernitede, değer yüklü üst anlatıların, ideolojilerin yerinden edilmesinin bir sonucu olarak siyasi olana bir "inşa" gözüyle bakılır; yani her türlü siyasi tavır sonuç niteliğinde genellemelerden değil belirsizliklerden, öznel yorumlardan ve çelişkilerden kaynaklanır. Postmodern anlayışa göre siyasi kavrayışlar da eşit ölçüde kesinlikten yoksun ve duruma bağlı niteliktedir. Çünkü postmodern anlayışta üst anlatılara, ideolojilere, olgulara, hakikate ya da bilime dayanarak bir siyasi stratejinin bir başkasından "daha iyi" olduğuna karar vermeyi sağlayacak bir temel

3 İlahi kaynaklı dinler tabiri esas itibarıyla İslam’a göndermede bulunmaktadır. Çünkü İslam inancına göre Allah tarafından gönderilen tüm dinlerin ortak adı İslam'dır. Zaten "İslam” kelimesi kavram olarak da bu anlamı içerisinde barındırmaktadır. İslam kelimesi Kur'an'da; biri genel, diğeri özel anlamda olmak üzere iki değişik muhtevâya büründürülerek zikredilir. 1. İlâhî hitâba mazhar olan peygamberler aracılığıyla gönderilen tüm hak/ semâvî dinlerin ortak adı. (Cins isim: Dînullah=Allah kaynaklı bütün dinler.) 2. Yalnızca son peygamber $\mathrm{Hz}$. Muhammed (S.A.V.)'e bildirilen ve İlâhî dinlerin bitiş halkasını teşkil eden inanç sisteminin adı. (Özel isim: el- İslâm=Yine Allah kaynaklı son barış ve esenlik dini.) Detaylı bilgi için bknz: Günay Tümer ve Abdurrahman Küçük, Dinler Tarihi, Ankara 1993 s. 175-176; Yusuf Alemdar, "Illâhî Din(ler) Mensuplarının Hayırlı Olanlarına Allah'ın Kur'an'da Öngördüğü Ortak İsim: Ümmet-i Kâime” http://eskidergi.cumhuriyet.edu.tr/makale/344.pdf 17.12.2015. http://www.islamansiklopedisi.info/dia/ayrmetin.php?idno=d090316 16.12.2015. 
yoktur (Rosenau, 2004: 202-203). Temel yoksunluğu söz konusu siyasi stratejilerin analiz edilmesini ve birbirleriyle kıyaslanmasını da zorlaştırmaktadır. Bu çerçevede ideolojiler de bir değerlendirme ölçütü olarak kabul edilmemekte ve postmodern siyasi anlayışta eski işlevini yerine getirememektedirler.

Postmodern siyasal anlayışın gelişiminde ve modern siyasal alanın yapısal dönüşümünde önemli bir değişim de ulus-devletlerde ve ulus-devlet yapılarında yaşanmıştır. Postmodern siyasal anlayış örgütlü bir toplumsal düzenden örgütsüz bir toplumsal düzene geçilmeye başlandığı bir devreye göndermede bulunmaktadır. Bu dönemde küreselleşme olgusuyla beraber insan ve mal hareketliliği giderek artmış ve herhangi bir işe, yere veya kurumsal yapıya olan bağlılıklar azalmıştır. Bu durumdan en çok etkilenen yapılardan biri ulus devletler olmuş ve bu durum ulus devletlerin egemenlik yapılarını ve sınırlarını da tartışmalı hale getirmiştir. Donnan ve Wilson'a göre, postmodern dönemde ulus-devlet sosyal, siyasal, ekonomik, çevresel ve kültürel içerikli sorunlarla karşı karşıya gelmiştir. İçte ve dışta egemenliği sağlayan ve sürdüren bir araç olan ulus-devletin karşılaştığı sorunların niteliği, kendi ulusuna karşı görevlerini yerine getirmesine engel oluşturmuştur (2002: 264-265).

20. Yüzyılın ikinci yarısından sonra iletişim ve ulaşım araçlarında meydana gelen gelişmeler, dünyanın giderek zaman ve mekân açısından daha da yakınlaşmasını, ekonomilerin içiçe geçmelerini ve dolayısıyla birbirlerine bağlı hale gelmelerini ve ulus aşırı güçlerin ortaya çıkmasını beraberinde getirmiştir. Bu dönemde özellikle iletişim ve ulaşım teknolojilerinde yaşanan gelişmeler sermayenin küresel ölçekteki hareketliliğini artırarak, şirketlerin daha kârlı bölgelere kaymalarını kolaylaştırmış ve dünyanın ulusal sınırlar eksenindeki siyasi bölüşümü sembolikleşmiştir (Şen, 2004: 210-213). Bu dönemde bir çok alanda yaşanan gelişmeler ulusal devletlerin ve ulusal tabanlı şirketlerin yerel düzenlemelerde etkisini azaltırken küresel ölçekli şirketlerin belirleyicilik ve düzenleyicilik niteliklerini giderek artıırmıştır. Üretim bandında yaşanan değişim, ağır sanayiden giderek hafif sanayiye kayış, hizmet sektörünün istikrarlı bir şekilde gelişmesi ve buna bağlı olarak beyaz yakalı işgücünde artış, sanayi üretiminin ekonomik olarak gelişmiş ülkelerden gelişmekte olan ülkelere doğru kayması ve küresel nitelikli şirketlerin üretim bandını giderek gelişmekte olan ülkelere kaydırmasıyla ulus devletin egemenlik yapıları yıpranmaya başlamıştır. Bu dönemde ulus devlet tarafından küresel kapitalizmin harekat alanını sınırlamaya dönük her politika, akışkan sermayenin ülkeden kaçmasına, ulus devletin ekonomik olarak sıcak paradan mahrum kalmasına ve ekonomik krizlere karşı çok kırılgan bir yapının ortaya çıkmasına neden olabilmektedir. Bu durum modern siyasal alanın belirleyici unsurlarından biri olan ulus devletin postmodern siyasal alanda belirleyicilik niteliğinin azalması anlamına gelmektedir. 1960'lardan itibaren siyasal, kültürel ve toplumsal alanlarda yaşanmaya başlayan yeni gelişmeler siyasal partilerin de kendilerini bu yeni duruma adapte etmelerini ve eski sınıfla ilişkili konuları geri plana atarak konjonktüre göre şekil almaya başlamasıyla sonuçlanmıştır. Bu çerçevede postmodern dönemde yeniden biçimlenerek ortaya çıkan ekonomik yapı ve bu yapının arkasındaki akışkan küresel kapitalizm giderek ulus-devletlerin egemenlik yapılarını ve düzenleyicilik rollerini aşındırmıştır.

$\mathrm{Bu}$ dönemde ulus-devletler, küresel bir sürecin parçası haline geldikçe, bir taraftan ulusal bütünlük zayıflamış, diğer taraftan küresel ekonominin etkilerine maruz kalmışlardır. Harvey'e göre, postmodern dönemde ulus-devletler, finans sisteminin 
küresel eşgüdümsel güçlenmesine paralel olarak sermaye hareketleri ve kendi mali ve ekonomik politikaları üzerindeki denetleme güçlerini büyük ölçüde kaybetmişlerdir (1999: 188-189). Drucker'a göre paranın merkez bankalarının kontrolünden; hatta, etkilerinden kurtularak "transnasyonel" bir nitelik kazanması, ulusal bir ekonomi politikasının oluşturulması ve uygulanmasını olanaksız kılarken; bilginin "transnasyonel" niteliği ulusal kültürün ve kimliğin varlığını tartışmalı hale getirmiştir. Bu iki gelişme aynı zamanda ulus devletin egemenliği sorununu ortaya çıkarmıştır (1993: 202-205).

Ulus devletlerin modern dönemde ulusal sınırlar içerisinde başkalarıyla paylaşılamayan en önemli niteliklerinden biri olan egemenlik yapıları bu dönemde giderek aşınmış ve egemenlik başka unsurlarla paylaşılır bir hal almıştır. Postmodern dönemde topluma ve siyasete dair karar alma süreçlerinde ulus devletin belirleyici olma konumu önemli oranda sarsılmıştır. Belirleyicilik konumu siyasal alanın dışında faaliyet gösteren unsurlara özellikle ekonomik unsurlara devredilmeye başlanmıştır. Bu durum ulusal ve uluslararası siyasal alanı gittikçe artan ölçüde ekonomik yapılara özellikle de sıcak, akışkan sermayeye daha çok bağlı/bağımlı hale getirmektedir. Sermayenin akışkan hale gelerek küresel düzeyde rahatça hareket etme yeteneği kazanmasıyla modern dönemin öznesi konumunda bulunan ve politika belirleme konusunda görece özgür olan ulus devlet de nitelik değiştirmeye ve akışkan sermayeye uygun bir biçim almaya zorlanmaktadır. Bu çerçevede ulus devlet yapısının sermayeyi elinde tutması klasik yapısını değiştirmesine bağlı görünmektedir. Bu yapısal değişim ise ulus devletin başta ekonomi politikası olmak üzere egemenlik yapısı ile yakından bağantılı bir çok politikasına sermayeyi de dahil etmesi gerekliliğini beraberinde getirmektedir. Bu ise hem ulus-devletin hareket alanını -özellikle iktidar etme alanını- daraltmış hem de ulus devleti esnek politikalar üretmeye zorlamıştır. Bundan dolayı ulus-devlet, belirleyici ve düzenleyici olma konumunu hızla kaybetmiştir. Küresel düzeyde işleyen ilişkiler ağı ve yerel, bölgesel ve ülkesel sınırları aşan etkileşimler belirleyicilik ve düzenleyicilik niteliği kazanarak ulusal bağları ve bağlılıkları zayıflatmakta, kültürel alışverişleri sıklaştırarak ulus aşırı topluluklar kurmakta, esnek ve akışkan kavramlarıyla ifade edilebilecek geçici bağlar üretmektedir. Bu çerçevede akışkan güçler modern dönemin siyasi kurumlarını devre dışı bırakarak iktidarı siyasal alanın dışına taşımaktadırlar.

Modern ve postmodern dönem siyasal alanı hakkında yukarıda yapılan açıklamalara göre modern ve postmodern dönemin temel siyasal yapısı aşağıdaki gibi tablolaştırılabilir.

\begin{tabular}{|l|l|}
\hline Modern Dönem & Postmodern Dönem \\
\hline Ulus Devlet & Küresel Kapitalizm \\
\hline Toplumsal Sinflar & Yeni Toplumsal Hareketler \\
\hline İdeolojiler & İdeolojilerin Reddi \\
\hline
\end{tabular}

Șekil 1: Modern ve Postmodern Dönemde Siyasal Alan Yapılanması

Tablodan da anlaşılacağı üzere postmodern dönem siyasetinin ana belirleyici konumuna yüzer-gezer bir güç olarak küresel kapitalizmin sınır tanımayan yapısı egemen olmuştur. Bu yapının herhangi bir bağlılığının olmaması ve bu yapıyı kontrol 
altında tutacak, olumsuzluklarını bertaraf edecek etkili bir mekanizmanın yokluğu postmodern dönem siyasetinin de belirsizliklerle dolu olmasını beraberinde getirmiştir. $\mathrm{Bu}$ açıdan bakıldığında postmodern siyasal ve toplumsal alanda herhangi bir konuda kesinlik veya garantiden bahsetmek yerine belirsizlikten söz etmek daha doğru olur. Bu çerçevede belirsizlik yaşamın hemen hemen her alanına sinmiştir ve insan her zaman her şeye hazırlıklı olmalıdır. Postmodern dönemde siyasal alanda yaşanan belirsizliğin ve bununla bağlantılı istikrarsızlığın önemli bir sebebi postmodern anlayışta düzen arayışının anlamsız ve gereksiz bir uğraş olarak görülmesidir. Postmodernite, aydınlanma ve rasyonaliteye karşı çıkarken, "yönteme/metoda hayır" ve "her şey uyar" sloganlarıyla geleneksel ve modern rasyonelitenin gerekli gördüğü "düzen"e karşı çıkmakta ve bu çerçevede herhangi bir düzen arayışını gereksiz bir çaba olarak değerlendirmektedir. Bauman'a göre [Modern siyasetin] önemli bir yönü rasyonel bir "düzen"in kurulması, korunması ve devamlılığının sağlanmasının bir görev olarak kabul edilmesi ve söz konusu bu düzenin bir "amaç" haline getirilmesidir. Buna karşılık postmodern dönemde herhangi bir düzen kurmak bir görev olarak algılanmadığı gibi herhangi bir düzen arayışı da akışkan sermayenin ve 'görünmez el'in yeteneklerine gereksiz bir müdahale ve gayretkeşlik olarak değerlendirilmektedir. Postmodern anlayışta bu müdahale mevcut durumu iyileştirmekten ziyade işi daha kötü bir duruma getirip içinden çıkılmaz bir hale getirebilecek risk oluşturucu çaba olarak görülmekte ve şüpheyle karşılanmaktadır (2000: 109-110). Bauman tarafından sürekli krizde olmak (2000: 156) olarak değerlendirilen bu durumu, postmodern siyasal ve toplumsal alanın en önemli tanımlayıcı unsurlarından biri olarak görmek mümkündür. Bu dönemde meydana gelen krizler hem oluşum süreçleri hem de etki alanları olarak geçmiş dönemdeki krizlerle karşılaştırıldıklarında hem çok daha hızlı gelişmeleri hem de ortaya çıktıkları yerle sınırı kalmamaları sonucunda, küreselleşme süreciyle ortaya çıkan karşılıklı bağımlıı̆ın da etkisiyle, zincirleme bir şekilde tüm dünyada hissedilerek çok daha geniş bir alana yansıdıkları görülmektedir. Bu sürekli kriz durumu ve krizlerin özellikleri siyasal alanın işleyişinin de değişmesini beraberinde getirmektedir. Düzen yoksunluğu, kaos ve krizin sürekliliği Baudrillard'ın da ifade ettiği "toplumsalın sonu"na işaret etmektedir. Baudrillard, siyasal alanın işleyişindeki bu durumu "politika uzun bir süreden bu yana yarı sportif, yarı eğlendirici bir özel eğlence programına dönüşmüştür" (2006: 37) şeklinde ifade etmektedir. Bu çerçevede modern ve postmodern siyaset anlayışına uygun olarak liderlik de farklı özellikler göstermektedir.

\section{Liderlik ve Postmodern Siyasi Liderlik}

Liderlik meselesi özellikle de siyasi liderlik meselesi toplumu bir bütün olarak ilgilendirdiğinden çokça merak edilen bir konudur. Bundan dolayı liderlik konusu ile ilgili geçmişten günümüze birçok teorik ve uygulamalı çalışma yapılmıştır. Bu çalışmalar genel olarak, liderin başkalarını neden ve nasıl etkilediği; bu etkileme sürecinde ne tür araçların ve mekanizmaların rol oynadığı ve liderlerin dayandığı meşruiyet kaynaklarının neler olduğu üzerine yapılmıştır. Liderlik, sosyal ve siyasal alanın hemen her düzeyinde gerçekleşebilmektedir. Siyasi liderlikte önemli olan toplumu veya toplumsal kesimleri peşinden sürükleyebilmek, onlara amaçlar belirlemek ve bu amaçlar doğrultusunda onları yönlendirebilmektir (Şimşek, 2006: 3). Liderlik konusunda yapılmış çalışmalara bakıldığında liderlik kavramı ${ }^{4}$ üzerinde uzlaşmaya varılmış kesin

4 Etimolojik olarak incelendiğinde, liderlik kavramı Anglo-Sakson kökenli bir kavram olup (lead) liderlik etmek, (leader) lider ve (leadership) liderlik kavramlarının kökeni "yol" veya "yön" anlamlarına gelmektedir. Lider kelimesinin İskandinavca (leadar), Almanca (leither), Flemenkce (leider) yazılışları İngilizce yazılışları ile 
bir tanımın bulunmadığı görülmektedir. Dönemsel olarak liderlik olgusuna yüklenen anlamlar değişmiştir. Bu çerçevede liderlik kavramına farklı açılardan birçok anlam yüklenmekte ve kavram farklı tanımlanmaktadır. Liderlikte "süreç", "etkileme", "ikna" vb. gibi kavramlar kilit rol oynamaktadır. Bu kavramlardan hareketle liderliğin çeşitli tanımlarını yapmak mümkündür. Liderlik, örgüt amaçlarının gerçekleştirilmesi için, örgüt personelinin gereksinimlerini, bireyler, gruplar ve çevre arasındaki ilişkileri düzenleyen, bireyler ve birimler arasında iletişim, etkileşim ve eşgüdümü sağlayan bir süreç (Özsalmanlı, 2005: 138). olarak tanımlandığı gibi bir grubu, topluluğu veya toplumu belirli amaçlar çerçevesinde bir araya getirebilme, onları bu amaçları gerçekleştirmeye sevketme bilgi ve becerisini etkin/etkili ve ikna edici bir şekilde kullanma, olarak da tanımlanmaktadır. Genel olarak bu çerçevede tanımlanan liderlik olgusu, içinde bulunulan dönemin egemen düşünsel yapısına ve gerekliliklerine göre yeni biçimler de alabilmektedir. İçinde bulunulan döneme göre liderliğin nitelikleri ve beklentilerinde farklılıklar olabilmektedir. Liderlik konusunda geliştirilen yaklaşımlara yakından bakıldığında, dönemsel şartlara göre şekillenen bir liderlik olgusunun oluştuğu ortaya çıkmaktadır. Modern liderlik, modern dönemin hâkim düşünce yapısı ve siyasal yapılarıyla biçimlenirken, postmodern liderlik, postmodern dönemin hâkim düşünce yapısı ve siyasal yapısı tarafından şekillenmiştir. Bu dönemlerde liderlik konusu üzerine yapılmış bir çok çalışma vardır. Genel olarak bakıldığında modern liderlikle ilgili üç tür yaklaşımın ön plana çıktığı görülmektedir. Bunlar; özellikler yaklaşımı, davranışsal yaklaşım ve durumsallık yaklaşımıdır. Postmodern liderlikle ilgili ise iki tür yaklaşımın ağırlık kazandığı görülmektedir. Bu yaklaşımlar ise etkileşimsel yaklaşım ve dönüşümcü yaklaşımdır.

\subsection{Modern Liderlik Yaklașımları}

Modern döneme hâkim olan siyasal yapı modern liderlik yaklaşımlarının da bu yapıya uygun bir şekilde ele alınmasını beraberinde getirmiştir. Bu dönemde yapılan çalışmalar, modern dönemin gereklerine ve içinde bulunulan dönemin şartlarına uygun bir şekilde lideri ele alan çalışmalardır. Modern liderlikle ilgili yapılan ilk çalışmalarda liderliğin, kişinin sahip olduğu kişisel özellikler dolayısıyla elde edildiği düşünülmüştür. Daha sonraki çalışmalarda liderlik için yalnızca kişisel özelliklerin dikkate alınmaşının yeterli olmadığı düşünülmüş ve liderlerin yönetimleri esnasındaki davranışlarının da liderliği ve liderlik olgusunu belirlediğine yönelik bir inanç oluşmuştur. Bu dönemde liderlerin davranışlarının önemli oranda liderin içinde bulunduğu durum ve şartlar tarafından belirlendiğine yönelik çalışmalar yapılmaya başlanmıştır. Liderlik konusu sürekli güncelliğini koruyan bir mesele olduğundan bilim çevrelerinde araştırılmaya devam etmektedir.

\subsection{1. Özellikler Yaklașımı}

Özellikler Yaklaşımı, modern liderlik konusunda ilk olarak geliştirilen yaklaşımlardan biridir. Özellikler yaklaşımı, ilk olarak Birinci Dünya Savaşı sırasında subaylar için duyulan gereksinim sonucu ortaya çıkmıştır. Bu yaklaşım özellikle zamanın askeri ve idari yöneticilerinin bir takım kişisel özellikleri incelenerek ortaya konulmuştur. $\mathrm{Bu}$ yaklaşımın temel amacı yaşadıkları dönemlere, hatta kendilerinden sonraki dönemlere de etki eden liderlerin yapılarını araştırarak liderlik için gerekli olan bireysel 
ve toplumsal özellikleri saptamak ve geleceğin liderlerini bu özellikler çerçevesinde yetiştirmektir. Bu yaklaşıma göre, bireyin sahip olduğu çeşitli kişisel ya da psikolojik özellikler bireyi lider yapmaktadır. Yaklaşım, temel olarak liderliğin doğuştan geldiğini, bireyin doğuştan liderlik yeteneklerine sahip olduğunu ve bu kişilerin her koşulda kendilerini lider olarak belli edeceklerini savunmaktadır (Şimşek, 2006: 10). Bazı kişilerin, çağdaşları üzerinde hâkim olacakları bir nüfuz sağlayan ve onları liderlik için şüphe götürmez bir şekilde diğerlerinden ayıran fıtri üstünlüğe sahip oldukları (Adair, 2005b: 17) varsayımından hareket eden bu yaklaşıma göre lider doğuştan taşıdığı fiziksel, duyumsal ve sosyal, düşünsel ve kişilik özellikleri bakımından diğer insanlardan farklı olmalıdır. Dolayısıyla, bir kişinin bir örgütte lider olarak kabul edilmesinin ve o örgütü yönetmesinin temel nedeni kişinin sahip olduğu özelliklerdir. $\mathrm{Bu}$ yaklaşıma uygun olarak yapılan ilk çalışmalarda, fiziksel özellikler (cinsiyet, yaş, boy), psikolojik testler sonucunda elde edilen kişisel özellikler (bağımsızlık, kendine güven, saldırganlık) ve kişilik testleri kullanılarak doğuştan var olan özellikler (zekâ, kararlıık) incelenmiştir. Buna göre, başarılı liderler başarılı olmayan liderlere kıyasla belirli özellik ve niteliklere daha fazla oranda sahiptirler (Aykan, 2002: 66). Özellikler yaklaşımı içinde değerlendirilmesi gereken önemli bir liderlik anlayışı karizmatik liderlik anlayışıdır. Özellikler yaklaşımının, bu en çok gündemde olan liderlik anlayışının, ayrı bir başlık altında ele alınması faydalı olacaktır.

\subsubsection{Karizmatik Liderlik Anlayıșı}

İlk olarak 1919'da, Max Weber'in iktidarın meşruluk kaynakları üzerine yapmış olduğu sınıflandırmada ortaya koyduğu karizmatik liderlik anlayışı sürekli olarak gündemde kalmıştır. "Meslek Olarak Siyaset" adlı konferansında temel olarak iktidarın meşruluk kaynağına yapmış olduğu atıflarla liderlik tiplerini sınıflandıran Max Weber, burada karizmatik liderlik tipini de açıklamıştır. Weber'e göre devlet, egemenlik altında bulunanların, egemenliği elinde bulunduranların öne sürdüğü otoriteye boyun eğmesiyle var olabilir. Egemenlik altında bulunanların hangi koşullarda ve niçin boyun eğdiklerini soran Weber, egemenliğin dayandığı içsel gerekçeleri ve dışsal araçları açıklayarak buna cevap vermiştir. Weber'e göre, egemenliği meşrulaştıran üç iç neden ve dolayısıyla üç yasallık temeli vardır: 1-Geleneksel otorite: Geçmişin otoritesidir. Yüceltilmiş geleneklerin ve göreneklerin kendilerine saygı duyan insanlara işlemiş alışkanlıkla yüceltilmiş geleneklerin otoritesidir. 2- Karizmatik otorite: Bir bireyin kişisel ve olağandışı yüceliğine dayanan otoritedir. Yani bir kişiye karşı duyulan tam bağlılık ve güvence, onun kahramanlığına ya da başka niteliklerine inanmaya dayanan otorite tipidir. 3- Yasal-ussal otorite: Yasal bir durumun geçerliliğine ve rasyonel kurallara duyulan inanç gereği zorlayıcı olan yetkiye inanmaya bağlı bir otorite tipidir. Burada yasalar tarafından konulmuş kuralların yerine getirilmesinde itaat beklenmektedir (Weber, 2006: 28-29).

Weber, bu üç otorite tipinin saf tipler olduğunu, gerçek hayatta bu saf tiplere pek az rastlandığını ifade etmektedir. Weber'e göre hangi egemenlik tipinin özelliklerinin ağır basacağını, içinde bulunulan dönemin özellikleri belirleyecektir. Ona göre, modern devletin tarihsel özelliği üçüncü otorite tipi, yani yasal-ussal otoritedir. (Weber, 2006: 29). Ancak Weber, bu tipler arasında ikincisine; yani karizmatik otorite tipine ayrı bir önem vermiştir. Karizmatik liderlik konusu sosyoloji, psikoloji, örgütsel davranış, tarih, yönetim, insan kaynakları ve siyaset bilimi gibi sosyal bilimlerin çeşitli dalları tarafından sıklıkla ele alınmıştır. Karizmatik lider kavramı özellikler yaklaşımında olduğu gibi 
karizmanın liderin bir özelliği olduğunu varsaymaktadır. Karizma kişilerarası çekicilik şeklinde kabul edilme ve desteklenmeyi önermektedir. Karizmatik liderler üyelerinin intiyaç, değer, kaynak ve özlemlerini kendi ilgilerinden kolektif ilgilere dönüştürmeye gayret ederler. Bundan dolayı izleyiciler liderlerinin misyonlarına gönülden bağlanırlar. Karizmatik liderler, izleyenleri açısından sıradan takdirin, sevginin, bağlıı̆̆ın ötesinde büyük bir çekim gücüne ve cazibeye sahip kişilerdir. Bu güç ve cazibe, bağlılığın yanı sıra sevgi ve saygıyı da içermektedir. Karizmatik liderler genellikle kriz ve kaos koşulları sonucunda ortaya çıkmaktadırlar. Ekonomik kriz, siyasi istikrarsızlıklar veya savaş durumu gibi koşullar toplumların çok sıkıntılı zamanlarıdır. Bu zamanlarda ortaya çıkan lider toplumsal algıda önemli bir yer edinmektedir (Baltaş, 2000: 105). Karizmatik liderlerin özellikleri; geleceğe dair heyecan verici bir vizyona sahip olma, yaptıkları işler ile örnek olma, sahip olduğu heyecan, coşku ve enerji ile diğerlerini motive etmek şeklinde sıralanmaktadır (Tengilimoğlu, 2005: 6-7). Bu yaklaşıma göre; karizmatik liderler kişisel becerileri ve özellikleri dolayısıyla kitleleri etkilemektedirler. Bu kişilerin iktidar güdüleri yüksek olduğu için lider olma güdüleri de yüksek olmaktadır. Karizmatik liderler tehlikeleri ilk olarak keşfetmeye yönelmekte ve bunları çözmeye çalışmaktadırlar. Bunun yanı sıra karizmatik liderler, izleyenlerinin istek ve değerlerine koşut benzer davranışlar göstermektedirler (Şimşek, 2006: 26). 1950'li yıllara gelindiğinde özellikler yaklaşımının ve karizmatik liderlik anlayışının liderliği açıklamada yetersiz kaldığını düşünen araştırmacılar toplumsal grupların işlev ve yapılarının çözümlenmesine dönük çalışmalara yönelmişlerdir. Bu çalışmaların sonucunda, lideri, üyesi olduğu grubun belirli sonuçlara ulaşabilmesi için, gruba yardımcı olacak davranışları yerine getiren kişi olarak ele alan "davranışsal yaklaşım” geliştirilmiştir (Şimşek, 2006: 11).

\subsubsection{Davranıșsal Yaklașım}

Davranışsal Yaklaşım, etkin liderlerin davranışsal karakteristiğinin ayırt edilmesi üzerine odaklanmıştır. Bu yaklaşım, liderin etkililiğini bireysel özelliklerin değil, davranış özelliklerinin belirlediğini ve liderlik davranışlarının da eğitim yoluyla kazanılabileceğini ileri sürmektedir. Liderin, grubun belirlediği amaçlara ulaşabilmesi için gerekli olan; izleyenlerle arasındaki iletişim türü, güdüleme şekli, izleyenlerini motive etme tarzı, grup bağııı̆̆ı, grup üyelerinin karar alma sürecine katkıları, emir verme tarzı, toplantıları yönetme şekli, grup içindeki kaynakları kullanışlı hale getirme gibi davranışları önemli olmaktadır (Şimşek, 2006: 12). Bu yaklaşımda etkin liderlerin ne oldukları değil, ne yaptıkları saptanmaya çalışılmıştır. Yönetim ve idare etme sürecinde liderin başarısının, sahip olduğu özelliklerden çok, liderlik sürecinde gösterilen davranışlardan kaynaklandığının ileri sürüldüğü bu yaklaşım; planlama, örgütleme, yürütme, eşgüdümleme, denetim, haberleşme, yetki devri, karar alma, motivasyon gibi fonksiyonları yerine getirirken sergileyeceği davranışların, liderin etkinliğini belirleyecek faktörler olduğunu ifade etmektedir (Bingöl, 1996: 244). Davranışsal yaklaşım, liderlik sürecinin anlaşılmasına önemli katkılarda bulunmakla birlikte çevreye ve koşullara ağırlık vermemesi yönünden eleştirilmiştir (Tengilimoğlu, 2005: 4-5). Bu eleştirilerin bir sonucu olarak içinde bulunulan çevre ve koşulları dikkate alan çalışmalar gündeme gelmiş ve durumsallık yaklaşımı geliştirilmiştir.

\subsubsection{Durumsallık Yaklașımı}

Durumsallık yaklaşımı, içinde bulunulan ve değişkenlik gösteren farklı koşulların değişik liderlik tarzları gerektirdiği ve en uygun liderlik davranışının koşullara ve 
duruma göre belirleneceği varsayımına dayanmaktadır. Bu yaklaşıma göre, lider olarak doğmak diye bir şey yoktur ve her şey duruma bağlıdır. Bazı durumlar bazı insanlarda, diğer durumlar da başka insanlarda liderlik duyguları uyandırmaktadır (Adair, 2005b: 28). Durumsallık yaklaşımında "en iyi" tek bir liderlik tarzı yerine duruma göre liderlik tarzı üzerine odaklanılmaktadır. Bu yaklaşımda lider, faaliyet gösterilen ortamın özellik ve gereksinimlerine göre ortaya çıkmaktadır. Bireysel özelliklerin bir önemi yoktur ve bireysel özellikler dikkate alınmaz. Bu yaklaşıma göre liderlik, yürütülen faaliyetlere göre farklı davranış biçimleri göstererek örgütparti mensuplarını ve takipçilerini güdülemeli ve onları başarılı olmaya yöneltmelidir. Bu süreçte liderliğin etkinliğini belirleyen faktörler: gerçekleştirilmek istenilen amacın niteliği, örgüt üyelerinin nitelikleri, yetenekleri ve bekleyişleri, liderliğin ortaya koyduğu organizasyonun özellikleri ile lider ve üyelerin sahip oldukları tecrübeler olarak ifade edilebilir (Sütçü, 2008: 48). Bu yaklaşıma göre, ortaya çıkacak farklı durumlara göre liderlerin yönetimde farklı yaklaşımlar sergilemeleri gerekebilir (Giderler, 2005: 69). Liderlik olayını koşulları da dikkate alarak açıklamaya çalışan bu yaklaşıma göre liderlik süreci, lider, izleyiciler ve koşulları arasındaki ilişkilerden oluşan karmaşık bir süreçtir (Tengilimoğlu, 2005: 5). Durumsal liderlik yaklaşımlarında, örgüt-parti kültürü, görevin yapısı, örgüt elemanlarının yapısı gibi durumsal değişkenlere bağlı olarak farklılaşan liderlik yaklaşımları geliştirilmiştir.

\subsection{Postmodern Liderlik Yaklașımları}

Postmodern dönem olarak da ifade edilen, içinde bulunduğumuz dönemin şartlarında gerek toplum yönetiminde gerekse örgütsel yönetimlerde etkili yönetimin gerçekleştirilmesi amacıyla pek çok yeni liderlik yaklaşımı üretilmiştir. Bu yaklaşımların ortaya çıkmasında, iletişim ve ulaşım araçlarında ortaya çıkan hızlı değişimlerle birlikte yaşanan küreselleşme olgusu ve postmodern dönemin insana ve insan davranışlarına yönelik düşünsel planda ortaya attığı yeni yaklaşımların da önemli payı vardır. Bu dönemde gerek dış çevrede beklenti ve bilgi düzeyinde görülen değişiklikler, gerekse yönetim ve organizasyon alanında ortaya çıkan gelişmeler ve yeni kavramlar, liderlik alanında da yeni yaklaşımların ortaya çıkmasına neden olmuştur (Tengilimoğlu, 2005: 5). Postmodern dönemin gerekleri göz önüne alındığında, bu dönemin intiyaçlarına cevap verebilmek için ortaya çıkmış ve birbiriyle bağlantılı iki tür liderlik yaklaşımının ön plana çıktığı görülmektedir. Bunlardan biri temelleri 1970’lerin başında atılan etkileşimci liderlik yaklaşımı iken diğeri ise 1970'li yılların sonunda geliştirilen dönüşümsel liderlik yaklaşımıdır.

\subsubsection{Etkileșimci Liderlik Yaklașımı}

Etkileşimci liderlik yaklaşımı temel olarak iş yaşamında uygulanmaya çalışılan bir yaklaşım olmakla birlikte siyasal hayatta da özellikle siyasi liderin yakın çevresine yönelik uygulanan bir yaklaşım tarzıdır. Bu yaklaşım, lider-izleyiciler ilişkisini bir "değiştokuş" süreci olarak görür ve mevcut yönetim tekniklerini verimli ve kurallara uygun biçimde uygulamaya koymaya çalışır. Bu liderler, kendilerini izleyenlerin gereksinimlerini önemser ve bu gereksinimlerin tatmin edilmesine öncelik verirler (Bakan, 2009:141). $\mathrm{Bu}$ yaklaşımda, liderin yakın çalışma arkadaşlarının sorumlulukları, liderin onlardan bekledikleri, sorumluların gerçekleştirmeleri gereken işler, lidere itaat ve yapılan işleri yerine getirmeleri karşılığında elde edecekleri ödüller açık bir biçimde ortaya konur. Yani, etkileşimci liderlik, lider ve izleyenleri arasında değişime dayalıdır. Etkileşimci 
liderlik, bir takım ödüller aracılığı ile izleyenlerin lideri takip etmesini sağlamayı amaçlayan, vurgunun izleyenlerin ya da astların kuralları doğru bir biçimde uygulaması üzerinde olduğu, bu amaçla sadece küçük çaplı ve rutin değişimleri gerektiren bir liderlik tarzıdır. Etkileşimci liderler, izleyenlerinin intiyaçlarını her iki tarafın katkılarının kabul edildiği ve ödüllendirildiği, karşılıklı olarak bağımlı bir ilişkiye girerek karşılamaya çalışırlar. Bu liderler, izleyenlerinin amaçlarına ulaşmalarına yardımcı olmak amacıyla yol gösterici bir hareket tarzı izlemeye özen gösterirler; izleyenleri de bu özene saygı duyar ve liderlerini takip ederler; çünkü onlara uymanın kendi çıkarlarına uygun olduğunu düşünürler (İşcan, 2006: 165). Etkileşimci liderler, izleyenlerinin geçmişten süregelen faaliyetlerini daha etkin ve verimli kılmak veya iyileştirmek gayesiyle onları motive etmeyi amaçlayan faaliyetleri yerine getirirler. Bu yaklaşımda liderler yetkilerini iş arkadaşlarını ve yakın çevresini ödüllendirmek, daha çok çaba göstermeleri için statü vermek ve izleyenlerini onore edici somut özendiricilerle ödüllendirmek biçiminde kullanırlar. Bununla birlikte, sorumlulukların yerine getirilmemesi durumunda yaptırım da uygularlar (Eren, 2008: 461-462; Şimşek, 2006: 27) Postmodern dönemin toplumsal yapısına ve siyasal beklentilerine cevap vermek amacıyla son dönem liderlik yaklaşımlarından biri de dönüşümcü liderlik yaklaşımıdır. Bu liderlik yaklaşımında etkileşimci liderlik yaklaşımında olan birçok unsur bulunmaktadır. Burada liderden beklenen değişime hızlı bir şekilde adapte olmak ve izleyenlerini de bu değişime hazırlamaktır.

\subsubsection{Dönüșümcü Liderlik Yaklașımı}

Dönüşümcü liderlik, liderlik yazınına görece yeni girmiş olan, 1980'lerden itibaren ağırlık kazanmaya başlayan bir yaklaşımdır. Dönüşümcü liderliğin ortaya çıkması ve yaygınlaşmasında postmodern toplum yapısının gereklerinin, yeni yönetim yaklaşım ve tekniklerinin, küreselleşmenin, baskıcı rekabet ortamının vb. gibi faktörlerin büyük rolü olmuştur (Bolat ve Seymen, 2003: 62-63). Dönüşümcü liderler hem etkileşimci liderlik özelliklerine sahip hem de bu özelliklere ek olarak gelecek odaklı bir yönetim tarzını benimsemiş, izleyicilerine olaylara yeni bakış açısıyla bakmayı salıkveren, grubun amaçlarıyla kendi kişisel amaçlarını uyumlaştıran, örgütlerinde gerekli değişim ve yenileşmeyi gerçekleştirerek üstün performans düzeyine ulaşabilmesi için mevcut ilkeleri sorgulayıp yeni ilkeler koyan liderlerdir (Bakan, 2009: 141). Dönüşümcü liderlik, geleneksel liderlikten farklı olarak, izleyenlere odaklanmaktadır. Gelişen iletişim ve ulaşım araçları, toplumsal kesimlerin ve bireylerin bu araçlara erişiminde ve kullanımında yaşanan hızlı gelişmeler, kamuoylarının ulusal ve uluslararası politikaları belirlemede artan etkisi, siyasi liderlerin de vatandaşlara ve kamuoylarına kulak vermelerini, onların istek ve beklentilerine göre politika belirlemelerini beraberinde getirmiştir. Bu açıdan dönüşümcü liderler izleyenleriyle çift yönlü iletişim kurmaktadırlar. Lider, toplumsal beklentileri gerçekleştirme yönünde çaba sarf etmekte ve bunu izleyenlerine kitle iletişim araçları kanalıyla ulaştırmaktadır. Dönüşümcü lider, bilgi ve becerilerini eski ve yeni kaynakları elde etmek ve harekete geçirmek, mevcut olan ve gelecekte beklenen sorunlara cevap vermek için hem siyasal grup içinde hem de dışında kullanmaktadır. Bu tür liderler değişimin kaçınılmaz olduğunu varsaymakta, değişimi gerekli görmekte ve değişime zamanında uymak için özel çaba göstermektedirler (Şimşek, 2006: 27).

Dönüşümcü lider, takdir edilen, saygı duyulan ve güvenilen kişidir. Dönüşümcü lider, kendi önemli değerlerini ortaya koyarak bu değerlerin haklıı̆̆ını ön plana çıkarmaya çalışır. Aynı zamanda, zor işlerin üstesinden gelerek izleyicilerine güven duygusunu 
aşılar. Amaçların, bağlıı̆̆ın önemini ve kararların etik sonuçlarını da izleyicilerine iletmeye çalışır. Bu durumda izleyiciler, lidere benzemeye çalışmakta ve kendilerini ortak amaçlar veya vizyon çerçevesinde onunla özdeşleştirmektedirler (Demir ve Okan, 2008: 76). Dönüşümcü liderler özgürlük, barış, yardımlaşma gibi değerler yoluyla izleyicileri yönlendirmeye gayret ederler. Korku, baskı, kıskançlık, aşırı rekabet gibi duygusal faktörleri devre dışı bırakmaya azami özen gösterirler (Kırel, 2000-2001: 47). Dönüşümcü liderler izleyenlerini belirli bir vizyona yöneltme ve yönlendirmeye çaba sarf ederler. Hem rasyonel araçların (örneğin değişim ve yenilik ihtiyacını haber vermek) hem de duygusal araçların (örneğin istek uyandıran, gelecek ile ilgili hayallerini ifade eden motive edici konuşmalar yapmak) kullanımı, izleyenlerin lidere olan güvenini arttırmakta ve lidere karşı güçlü bir bağıılık oluşturmaktadır.

\subsection{Postmodern Siyasi Liderlik}

Buraya kadar açıklanan liderlik yaklaşımları, her dönemin toplumsal, siyasal, çevresel ve ekonomik koşullarının, o dönemin liderden beklentilerini ve liderlik özelliklerini önemli ölçüde belirlediğini ortaya koymuştur. Buna göre, yukarıda ifade edilen ve postmodern dönem liderliğini açıklamaya yönelen etkileşimci ve dönüşümcü liderlik yaklaşımları postmodern dönem siyasi liderliğini tam olarak açıklayamasalar da postmodern siyasi liderlik için yararlı birer yaklaşımdırlar. Bu yaklaşımların postmodern dönemin siyasi liderliğini tam olarak açıklayamamalarının en önemli nedeni, postmodern döneme egemen olan karmaşıklık ve belirsizlik kadar postmodern dönemde sürekli bir değişim ve dönüşümün yaşanmasıdır. Bununla birlikte, postmodern dönemin niteliklerini ve postmodern liderlik yaklaşımlarını da dikkate alarak postmodern siyasi liderliğin taşıdığı özellikleri tespit etmek mümkündür. Bu amaçla, postmodern dönem siyasal hayatı ve postmodern siyasi liderlik üzerine yapılan çalışmaları göz önünde bulundurarak ve yukarıda açıklanan liderlik yaklaşımlarını da dikkate alarak postmodern siyasi liderliğin özelliklerini modern liderlikle karşılaştırmalı bir şekilde analiz etmek yararlı olacaktır.

Modernitede fail ve aktif olan öznenin postmodern anlayışta aktif faillik özelliğinden uzaklaştırılarak pasifleştirilmesi; modernitede egemen olan üretim ilişkilerinden tüketim ilişkilerine geçiş; küreselleşme olgusu; sosyal, siyasal ve ekonomik alanlarda yaşanan değişim ve dönüşümle birlikte yine aynı alanlarda meydana gelen krizlerin büyüklüğü ve sürekliliği, dijitalleşmenin yaygınlaşması, bürokratik sistemin zayıflayarak esnekliğin giderek önplana çıkması ve kitle iletişim araçlarında yaşanan gelişmeler, postmodern liderlik anlayışının modern liderlik anlayışından farklılaşmasını beraberinde getirmiştir. Modern liderlik yaklaşımlarında görüldüğü gibi modern liderden öncelikle aktif bir özne olarak belirli kişisel özelliklere sahip olmasıyla birlikte bu özelliklerini davranışsal olarak da ortaya koyması beklenmektedir. Bu çerçevede modern liderin karizmatik olması, zeki, iyi eğitimli, insanları belli bir amaç etrafında toplayabilme ve onları yönlendirebilme yeteneği ve becerisi öncelikle beklenmektedir. Modern lider, sorunları rasyonel bir düşünsel çerçevede çözme gayreti içerisindedir. Postmodern lider ise öncelikle esneklik felsefesiyle hareket eden, karşılaştığı sorunları çözümlerken herhangi bir rasyonaliteye dayanma ihtiyacı duymadan çözümler arayan bir anlayışla hareket etmektedir. Postmodern lider sürekli bir kriz ve belirsizlik ortamında ortaya çıkan çatışmaları yöneten, sürekli değişim anlayışı çerçevesinde sürdürülebilir bir yönetimi ortaya koymaya çalışmaktadır. Postmodern lider sürekli bir değişim, kriz ve belirsizlik ortamında olması nedeniyle kendini sürekli güncelleyen ve buna hızı bir uyum sağlayan yapıdadır. Postmodern lider, yönlendiren olmaktan çok yönlendirilen, 
değişim ve dönüşümleri planlayan değil bunlar tarafından biçimlenen bir konumdadır. Çünkü, postmodern liderlik yaklaşımlarında da ifade edildiği gibi postmodern lider yaşanan hızlı değişimlere ve toplumun beklentilerine göre kendini dönüştürmeye çalışan bir karakterdedir. Bundan dolayı, postmodern lider toplumsal beklentilere karșılık vermek ve kendini toplumla uyumlu hale getirmek için sürekli bir enformasyon akışına da gereksinim duymaktadır. Postmodern lider bu enformasyon gereksinimini ise genellikle kitle iletişim araçları ve sosyal medyadan elde etmektedir. Bu dönemde, kitle iletişim araçlarından ve sosyal medyadan gerektiği gibi yararlanmayan siyasi lider, toplumun nabzını tutmayacağından siyasi hayatı devamlı bir tehlike altındadır.

Postmodern dönemde ekonomik alanda tüketici odaklı bir piyasa yapılanması dahilinde esnek örgütlenmenin oluşturulması, neoliberal politikalar çerçevesinde özelleştirmelerin teşvik edilmesi, siyasi alanda yerelleşmenin ve ademi merkeziyetçi politikaların geliştirilmesiyle mikro devletin oluşturulması çalışmaları önplana çıkmaktadır. Söz konusu bu politikalar ve uygulamalar toplumsal ve ekonomik ilişkilerin de önemli bir belirleyicisi konumunda yer almaktadır. Öncelikle bu politika ve uygulamalar sosyo-ekonomik düzeyde esnek ilişkilerin ortaya çıkmasında kilit bir rol oynamaktadır. Toplumsal düzeyde ortaya çıkan esnek ilişkiler postmodern liderin de esnek ilişkiler çerçevesinde biçimlenmesini beraberinde getirmektedir. Bu çerçevede postmodern liderin toplumu yönlendiren, onu biçimlendiren bir lider olmaktan çok toplumsal gelişmelere göre şekil alan, konjontürel değişimlere aşırı duyarlı ve uyumlu bir yaklaşım içerisinde olduğu görülmektedir. Geleneksel ve modern liderlikte lider fail ve aktif bir özne pozisyonunda, yani bireyleri, grupları veya bir bütün olarak tüm toplumu değiştirmeye çalışan bir konumda, yer alırken postmodern zamanların lideri pasif bir konumda yer almakta ve etkileyen değil etkilenen, biçimlendirmeye çalışan değil biçimlendirilmeye çalışılandır. Postmoderniteyi yaşayan toplumlara bakıldığında bu toplumlarda seçimleri kazanan siyasi liderlerin özellikleri arasında esnekliğin önplana çıktığı görülmektedir. Barack Hüseyin Obama, Angela Merkel, David Cameron ve François Hollande'ın seçim başarılarına ve politik uygulamalarına bakıldığında bu liderlerin esnek ilişkiler çerçevesinde hareket etmeye çalıştıkları, konjonktürel gerekliliklere göre politika geliştirdikleri ve hareket alanlarını sınırlandıracak keskin bir dil kullanmak yerine daha çok esnek hareket alanı sağlayacak olan bir siyasal söylemi tercih ettikleri görülmektedir. Bu çerçevede denilebilir ki esneklik kavramını postmodern siyasal liderlerin ortak bir özelliği olarak görmek mümkündür.

Modern dönemde hiyerarşik/dikey ve bürokratik örgüt yapıları söz konusu iken postmodern dönemde bu yapıların yerine, yatay ilişkiler ve esnek kuralların belirlediği bir yapılanma söz konusudur. Bu yapılanma esneklik temelinde toplumsal ilişkileri de dönüştürmektedir. Üretim ilişkilerinden çok tüketim ilişkilerinin egemen olduğu postmodern dönemde, postmodern lider de bu ilişkilerin baskısı altında kalmakta ve uyum sağlamaya çalışmaktadır. Bu nedenle, postmodern liderin esneklik nedenlerini bu dönemde önplana çıkan tüketim ilişkilerinde aramak yanlış olmayacaktır. Tüketim ilişkilerine hakim olan esneklik toplumsal hayatın da hemen hemen her alanında hissedilmektedir. Buradan hareketle esneklik uygulamalarının sosyo-ekonomik ilişkilerde yeni bir değer olarak belirmeye başladığı ifade edilebilir. Yere, işleve ve zamana bağlı/bağımlı konularda değişme ve esneme siyasal, tarihsel, ekonomik, kültürel vb. bir çok alanda az veya çok ortaya çıkabilmektedir. Postmodernite açısından yeni bir değere dönüşen esneklik olgusu, esnek birey ve çalışanı önermekte ve bunları uygulamalarıyla yeniden üretmektedir. Bu birey ve çalışan başarılı olmak istiyorsa 
esnek yer, zaman, iş ve niteliğe sahip olmalıdır. Bu yapı içerisinde toplumsal değişimleri yakından takip etmek zorunda olan postmodern lider de esneklik uygulamalarından etkilenmekte ve buna uyum sağlamaya çalışmaktadır.

Modern liderlikte yukarıda ifade edilen modern liderlik yaklaşımlarından da anlaşılacağı gibi kazan-kaybet olgusu, katı ilişkiler, klikleşme ve gruplaşma, korku ve kontrole dayalı bir yönetim tarzı hâkimdir. Bununla birlikte modern liderler kurgulayıcı, emir veren, eleştiren, belli bir inanç sistemine veya ideolojiye bağlı olan, kendinden çok toplumu merkeze koyan bir yaklaşım sergilemektedirler. Bundan dolayı modern liderlik anlayışında, postmodern anlayış, bürokrasiyi zayıflatma, ilişkileri esneklik üzerine kurma, farklılığa ve çeşitliliğe vurgu yapma, toplum çıkarlarını ikinci plana atma, kişisel çıkarlar için sistemi kullanma ve yüzeysel olma gibi açılardan eleştirilir (Aytaç, 2003: 62-63). Buna karşılık postmodern lider modern liderlikte olduğu gibi artık yol gösteren bir model değil bireylerin taleplerine göre hareket eden ve koşullara göre şekil alan bir yapıdadır (Yıldız, 2013: 222). Postmodern liderlikte, etkileşimci ve dönüşümcü liderlik yaklaşımları da dikkate alındığında, farklılıklar, çeşitlilikler ve çelişkiler kullanılarak etkililiğin gerçekleştirileceği öngörülür. Modern lider kendini öteki üzerinden kurarken; postmodern lider karşıt kültürleri, grupları ve ideolojileri dışlayan değil; onları içine alan ve anlamaya çalışan bir karakterdedir. Postmodern liderin, postmodern bireyin taşımış olduğu nitelikleri kendisinde bulundurması veya en azından bu nitelikleri kimliğinin bir "öteki"si olarak taşımadığını göstermesi gerekir. Burada önemli olan liderin bu nitelikleri taşıyıp taşımaması değildir. Bunun hedef gruplar nezdinde öyleymiş gibi algılanmasıdır. Yıldız'a göre, postmodern liderlik klasik liderliğin birey tarafından talep edilen niteliklerini iletişim kaynağı olarak taşımaktadır. Klasik ve modern anlamda liderlik için güven, dürüstlük, çalışkanlık, doğalıı kavramları hedef kitleyi etkilemede önemlidir. Postmodern liderlik aynı özellikleri iletişim kaynağı olarak taşımalıdır; ancak, gerçekte öyle olması ile "öyleymiş gibi" algısı oluşturması arasındaki mesafe azalmıştır (2012: 128). Bu açıklamalardan yola çıkarak modern ve postmodern siyasi liderliğin taşımış olduğu özellikler aşağıdaki gibi tablolaştırılabilir.

\begin{tabular}{|l|l|}
\hline Modern Liderlik & Postmodern Liderlik \\
\hline Statüko & Sürekli Değișim \\
\hline Karizmatik & Karizmatik (İmaj olarak) \\
\hline Zeki & Zeki (İmaj olarak) \\
\hline İdeoloji Bağımlı & İdeolojiden Arınmıșlık \\
\hline Katı Ilișkiler & Esnek Ilișkiler \\
\hline Dikey Hiyerarși & Yatay Ilișkiler \\
\hline Rasyonel & Rasyonel - Konjonktürel \\
\hline Uzun Vadeli Planlama & Kısa Vadeli Planlama \\
\hline Düzen & Kaos/Kriz \\
\hline Ahlaki Yükümlülük-Sorumluluk & Ahlaki Sorumluluk- Zorunlu Değil \\
\hline Tekil Hakikatlere İnanır & Çoğul Hakikatlere İnanır \\
\hline Tekil Anlamlandırma & Çoğul Anlamlandırma \\
\hline Yerleșik Kișisel Kimlik & Değișken Kișisel Kimlik \\
\hline
\end{tabular}




\begin{tabular}{|l|l|}
\hline Bütüncül Karakterde & Parçalı Karakterde \\
\hline Aktif Özne / Fail & Pasif Özne \\
\hline Biz & Ben \\
\hline Etkileyen & Etkilenen \\
\hline Rol Model & - \\
\hline Uzman & Disiplinlerarası Çalıșan \\
\hline
\end{tabular}

Șekil 2: Modern ve Postmodern Liderliğin Özellikleri

Tablodan da anlaşılacağı üzere mevcut modern ve postmodern liderliğin özellikleri birbirlerinden oldukça farklıdır. Buna göre, modern lider, statükocu, ideoloji bağımlı, rasyonel, uzun vadeli planlamayla hareket eden, uzun bir zaman diliminde yerleşmiş bir kişisel kimliğe ve bütüncül bir karaktere sahip olan, yapmış olduğu işlerde ahlâki bir sorumlulukla hareket etmeye çalışan -en azından ahlâkilik ile değerlendirilen-, alanında uzman, toplumu kendi inançları çerçevesinde dönüştürmeye çalışan aktif bir öznedir. Bununla birlikte, modern siyasi lider zeki, karizmatik, katı ilişkiler çerçevesinde ast ve üstler arasındaki hiyerarşiye önem veren aynı zamanda toplumun menfaati için kendi menfaatlerinden vazgeçen ve biz duygusuyla hareket eden bir bireydir. Buna karşılık, postmodern siyasi lider postmodern dönemin muğlâklığı ve belirsizliği ile birlikte sürekli değişim felsefesiyle hareket eden, ideolojilerden ve üst anlatılardan bağımsız olarak konjonktüre göre pragmatist-rasyonel bir pozisyon alan, kısa vadeli planlamayı seven, değişken kişisel kimliğe ve parçalı bir karaktere sahip olan, yapmış olduğu işlerde ahlaki sorumluluğu zorunlu olarak görmeyen, ancak, bunu kişisel bir tercih olarak algılayan, disiplinler arası çalışan ve mevcut gelişmelerden etkilenen pasif bir öznedir. Postmodern siyasi lider iletişim kaynağı olarak yani algısal olarak karizmatik ve zeki görünen, esnek ilişkiler çerçevesinde ast ve üstler arasındaki yatay iletişime önem veren, toplumun menfaati ile kendi menfaatini birbirine uyumlu hale getirmeye çalışan, son kertede kendisini önceleyen ve ben güdüsüyle hareket eden parçalı bir bireydir. Postmodern dönemin siyasi lideri bu özellikleri ile postmodern dönem insanına herhangi bir güven ve umut verememekte, onları küresel kapitalizmin ve bununla bağlantılı yüzer-gezer güçlerin düzenleyici etkilerine açık halde bırakmaktadır.

\section{Sonuc}

Postmodern dönem tanımlaması içerisinde siyasetin yeni temeller üzerinden yapılanışını ve buna bağlı olarak toplumu bir bütün olarak ilgilendiren siyasetin sözcülerinin özelliklerinin dayandığı temelleri ve siyasi liderlerin ne tür özellikler taşıdığını araştırmak ve tespit etmek amacında olan bu çalışmada, postmodern siyasetin temel niteliklerinden birisinin "esneklik" olduğu, postmodern siyasette ve siyasetçide katılığa yer olmadığı ve siyasi yapının esneklik üzerine kurulduğu değerlendirmesine ulaşıımıştır. Bu çerçevede, postmodern dönem siyasal alanının modern dönemde egemen olan siyasal alan yapılarını eleştiriye tabi tutarak köklü bir dönüşüme zorladığı ve modern dönem siyasal yapılarının geç modern dönemde belirleyicilik niteliklerini önemli oranda yitirdikleri tespit edilmiştir. Bu tespiti yapmak için çalışmada modern döneme hakim olan siyasal yapı ile postmodern döneme egemen olan siyasal yapı ele alınıp tartışılmıştır. Buna göre, modern dönem siyasal yapısı temel olarak üç unsur üzerine kurulmuştur: devletin siyasal yapılanmasında ulus devletin 
ortaya çıkması; sanayi devriminden sonra Batı'da toplumsal tabanda ekonomik temelli sınıfların oluşması; bu sınıfları temsil eden ve birbirine rakip farklı ideolojilerin ortaya çıkması. Modern dönemde siyasetin işleyişini belirleyen bu birbiriyle bağlantılı ve belli bir bütünlük oluşturan unsurların meydana getirdiği genel yapı modern liderin de bütünlüklü bir yapı ortaya koymasını gerektirmiştir.

Postmodern dönemde ise modern dönemin siyasal yapısını belirleyen sınıf, ideoloji ve ulus-devlet gibi yapılar aşınmaya başlamıştır. Bu dönemde siyasal ve toplumsal alanda yaşanan parçalanmışlık postmodern siyasetin işleyişini de belirleyen en önemli etkenlerden biri olmuştur. Bu çerçevede, postmodern dönem siyasal alanının yapısal dönüşümünde önemli bir değişim ulus devletlerde ve ulus-devlet yapılarında yaşanmıştır. 20. Yüzyılın ikinci yarısından sonra iletişim ve ulaşım araçlarında meydana gelen gelişmeler, dünyanın giderek zaman ve mekân açısından yakınlaşmasını ve küreselleşme olgusunun ortaya çıkmasını beraberinde getirmiştir. Bu durum en çok ulus-devletleri etkilemiş, ulus-devletlerin egemenlik alanlarını sınırlandırmıştır.

Postmodern dönemde ulus-devletlerin egemenlik yapılarını etkileyen toplumsal ve ekonomik yapıda yaşanan değişimlerle birlikte modern döneme hâkim olan siyasal yapı da önemli oranda dönüşüme uğramıştır. Bu dönüşüm özellikle 1960'lı yıllarla birlikte, Batılı sanayi toplumlarında yeni değerler ve yeni toplumsal hareketlerin oluşmaya başlamasıyla ortaya çıkmıştır. Ekonomik temelli toplumsal sınıflardan ayrı bir nitelik taşıyan bu yeni toplumsal hareketler merkezsiz, yerel, düzensiz ve parçalı bir durumdadırlar. Postmodern anlayışa uygun olarak tutarlı bir örgüt yapısından mahrum olan bu toplumsal hareketler, postmodern dönemin belirsiz yapısından kaynaklanan uzun vadeli stratejiler izleyememektedirler. Bununla bağlantılı olarak Batı'da sanayi devrimiyle ortaya çıkan sınıfsal yapı ve bu yapının temsilcileri rolünü oynayan ideolojiler ve ideoloji/sınıf bağımlı siyasal partiler de sınıfsal yapının aşınmasıyla beraber siyasal alanda belirleyici olma konumlarını yitirmişlerdir. Bunun bir sonucu olarak postmodern dönemde ideolojiler de gözden düşmüş ve siyasetin işleyişinde belirleyici olma konumlarından önemli oranda uzaklaşmışlardır. Postmodern anlayışta ideolojiler ve üst anlatıların yerine küçük anlatılar geçirilerek, göreceliğe ve farklılığa aşırı bir vurgu yapılmaktadır. Postmodernist anlayışın belli bir bütünlüğe sahip yapılar ve büyük anlatılarla herhangi bir bütünlük oluşturmayan yapılar ve küçük anlatılar arasında değer ve üstünlük açısından herhangi bir fark görmeyişi bu yapılar ve anlatılar arasında sınırların muğlaklığını, geçişgenlikleri ve esnekliği önplana çıkarmıştır. Bununla birlikte, özellikle ileri kapitalist ülkelerde ve modern sonrasını yaşayan seküler Batı toplumlarında hayatın her alanında yaşanan parçalanmışlık da bu geçişgenliği ve esnekliği beslemiştir. Bundan dolayı bu dönemde özellikle ileri kapitalist ülkelerde ve seküler toplumlarda hemen her alanda egemen olmaya başlayan değer "esneklik" olmuştur. Bu kavram, postmodern dönemde katılığa yer olmadığını, her türlü katılığın yerini esnekliğin ve esnek ilişkilerin aldığını göstermesi açısından postmodern dönemin tanımlanmasında işlevsel bir rol oynamaktadır. Esneklik kavramının postmodern döneme hâkim olan kavram olması, bu kavramın siyasi liderlik anlayışına yansımasını da beraberinde getirmiştir. Çünkü bir toplum nasıl bir yapıya sahipse, toplumu yönetenler de aynı yapıya sahip bir nitelik ortaya koymaktadırlar. Geleneksel ve modern siyasi liderlik anlayışına hâkim olan toplumun önünde giden ve topluma bir yön vermeye çalışan liderlik yapısı postmodern liderlik anlayışında tersine dönmüştür. Buna göre, postmodern siyasi liderlik toplumun arkasından giden, toplum tarafından şekillendirilen bir yapıya sahiptir. Postmodern lider, çeşitli kamuoyu araştırmalarından edindiği toplumsal tercihlerle ilgili 
veriler ışığında söylemlerini şekillendirmekte, kendisini biçimlendirmekte, politikalarını bu doğrultuda oluşturmaktadır. Bu çerçevede toplumu şekillendirmeye ve kapsamlı bir anlatı dahilinde belli bir kalıba sokmaya çalışan geleneksel ve modern liderlik anlayışının aksine postmodern liderin bizzat kendisi değişen koşullara göre şekil alan ve toplumsal talepler karşısında "esneklik" özelliği ortaya koyan bir yapıya sahip görünmektedir. Geleneksel ve modern lider de elbette belli sınırlar dahilinde esnek bir yapıya sahip olmuştur. Ancak bu esneklik durumu postmodern dönemde olduğu gibi kural değil istisnadır.

Mevcut postmodern durum göz önüne alındığında siyasal alanın etkili bir failden yoksun olarak kontrol altında olmayan küresel kapitalizmin belirleyiciliği altında şekillenmesi, bir bütün olarak toplumu tedirgin eden ve güvenden uzaklaştıran bir durum ortaya koymaktadır. Bu durum toplumsal, siyasal, kültürel ve ekonomik alan başta olmak üzere hayatın birçok alanında kriz durumlarını beslemektedir. Bu çerçevede, postmodern dönemin içinde bulunduğu kriz, belirsizlik ve kaos ortamlarının en aza indirilmesi için kitlelerle beraber siyasi liderin de intiyaç duyduğu güven ve bağlılıkların egemen olduğu bir ortamın inşa edilmesi gerekmektedir. Bu ortamın inşa edilmesinde ise yine toplumun önünde giden ve topluma belirli bir yön çizmeye çalışan liderlerin payı önemli olacaktır. Sonuç olarak postmodern dönemde hem siyasi lideri hem de toplumu bir bütün olarak yüzer-gezer ve bağsız güçlerin egemenliğinden kurtaracak bir siyasi liderlik anlayışının hakim kılınması gerekmektedir. Bu açıdan postmodern dönem siyasi liderinin kitleleri yönlendirebilecek, onları belli bir proje çerçevesinde motive edebilecek, aynı zamanda onları yaptığı projelerin bir parçası haline getirebilecek ve kolektif/ortak aklı devreye sokacak bir nitelikte olması gerekir. Postmodern dönemde siyasal alan, liderlik yeteneğini ön plana çıkaran, entelektüel/ilmi sermayeye daha fazla önem veren, küresel gelişmeleri yakından takip eden ve meşru toplumsal beklentileri iletişim araçlarını etkin bir şekilde kullanmak yoluyla elde ederek bu beklentileri karşılayan siyasi liderlere gereksinim duymaktadır. Bu tür bir siyasi liderlik yukarıda açıklanan liderlik yaklaşımlarından karizmatik liderlik yaklaşımı ile dönüşümcü liderlik yaklaşımının bir uyumunu gerektirmektedir. Buradaki uyum, siyasi liderin yalnızca kendi özelliklerine ve saygınlığına dayanarak toplumu dönüştürmeye çalışmamasını, toplumun meşru genel istek ve beklentilerini ortak yarara ve adalete hizmet edecek şekilde göz önünde bulundurmasını, ortak aklı devreye sokmasını ve küresel çapta yaşanan değişimleri de dikkate alarak gerekli değişim ve dönüşümleri kontrollü bir şekilde yürütmesini ifade etmektedir. Böyle bir siyasi liderlik yaklaşımı, hem yaşanan değişimlerin yeni krizlere dönüşmesine engel olması hem de güven ve bağlılıkların egemen olduğu toplumsal bir yapının inşa edilmesi anlamında önemli katkılarda bulunabilir ve postmodern dönemin belirsizliklerle dolu dünyasında ortaya çıkabilecek olumsuz durumlara karşı etkili bir nitelik taşıyabilir.

\section{Kaynakça}

Adair, John (2005a). Kışkırtıcı Liderlik, İstanbul: Alteo Yayınları.

Adair, John (2005b). Etkili Liderlik, İstanbul: Babıali Kültür Yayıncılığı.

Alp, Salih (2009). "Refah Devleti Düşüncesinin Gelişimi ve Bir Liberal Alternatif Olarak Üçüncü Sektör", Maliye Dergisi, Sayı 156, Ocak-Haziran, 265-279. 
Aykan, Ebru (2002). Girişimcilik ve Girişimcilerin Liderlik Davranışları, Yayımlanmamış Yüksek Lisans Tezi, Erciyes Üniversitesi Sosyal Bilimler Enstitüsü, Kayseri.

Aytaç, Tufan (2003). "Post-modern Eğitim Yöneticisi”, 21. Yüzyıl Eğitim Yöneticilerinin Yetiştirilmesi Sempozyumu, 16-17 Mayıs 2002, Ankara: Ankara Üniversitesi Eğitim Bilimleri Fakültesi, Yayın No: 191.

Bakan, İsmail (2009). “Liderlik Tarzları ile Örgüt Kültürü Türleri Arasındaki İlişkiler: Bir Alan Çalışması" TiSK Akademisi, 4 (7): 138-172.

Baltaş, Acar (2000). Değişimin İçinden Geleceğe Doğru Ekip Çalışması ve Liderlik, İstanbul: Remzi Kitabevi, 1.Baskı.

Baudrillard, Jean (2006). Sessiz Yığınların Gölgesinde - Toplumsalın Sonu, (Çev: Oğuz Adanır), Ankara: Doğu Batı Yayınları, 3. Basım.

Bauman, Zygmunt (2000). Siyaset Arayışı, (Çev: Tuncay Birkan), İstanbul: Metis Yayınları.

Bell, Daniel (2013), İdeolojinin Sonu, Ellilerdeki Siyasi Fikirlerin Tükenişine Dair, (Çev: Volkan Hacıoğlu), Ankara, Sentez Yayıncılık, 1. Basım.

Bingöl, Dursun (1996). Personel Yönetimi, İstanbul: Beta Basım Yayım, 2. Baskı.

Bolat, Tamer ve Seymen, Oya Aytemiz (2003). "Örgütlerde İş Etiğinin Yerleştirilmesinde Dönüşümcü Liderlik Tarzının Etkileri Üzerine Bir Değerlendirme”, Balıkesir Üniversitesi Sosyal Bilimler Enstitüsü, Sosyal Bilimler Dergisi, 6 (9): 59-85.

Demir, Halis ve Okan, Tarhan (2008). "Etkileşimsel ve Dönüşümsel Liderlik: Bir Ölçek Geliştirme Denemesi”, İstanbul İktisadı Enstitüsü Dergisi, Yıl: 19, Sayı: 61: 72-90.

Donnan, Hastings ve Wilson, M. Thomas (2002). Sınırlar, (Çev: Zeki Yas), Ankara: Ütopya Yayınları.

Drucker, Peter F. (1993). Kapitalist Ötesi Toplum, (Çev: Belkıs Çorakçı), İstanbul: İnkılap Kitabevi Yayınları.

Eren, Erol (2008). Örgütsel Davranış ve Yönetim Psikolojisi, İstanbul: Beta Basım Yayım, 11. Basım.

Featherstone, Mike (2005). Postmodernizm ve Tüketim Kültürü, (Çev.: Mehmet Küçük), İstanbul: Ayrıntı Yayınları.

Giderler, Ceren (2005). Yöneticilerin Kişilik Tarzları ile Liderlik Davranışları Arasındaki İlişki ve Eczacıbaşı Topluluğu'nda Uygulama, Yayımlanmamış Yüksek Lisans Tezi, Dumlupınar Üniversitesi Sosyal Bilimler Enstitüsü, Kütahya.

Harvey, David (1999), Postmodernliğin Durumu, (Çev. Sungur Savran), İstanbul: Metis Yayınları. İşcan, Ömer Faruk (2006). "Dönüştürücü/Etkileşimci Liderlik Algısı ve Örgütsel Özdeşleşme ìlişkisinde Bireysel Farklılıkların Rolü”, Akdeniz Üniversitesi, İ.i.B.F. Dergisi, 6 (11): 160-177. 
Jameson, Fredric (2005), Kültürel Dönemeç, (Çev.: Kemal İnal), Ankara: Dost Kitabevi.

Kellner, Douglas (2000). "Toplumsal Teori Olarak Postmodernizim: Bazı Meydan Okumalar ve Sorunlar", (Der. ve Çev. Mehmet Küçük), Modernite versus Potmodernite, Ankara: Vadi Yayınları, 367-404.

Kırel, Çiğdem (2000-2001). "Liderlik Davranış Biçimleri Konusuna Yeni Bir Yaklaşım: Karizmatik Liderlikten Dönüşümsel Liderliğe” Eskişehir: Anadolu Üniversitesi Sosyal Bilimler Dergisi: 43-59.

Lyotard, Jean François (1994). Postmodern Durum, (Çev: Ahmet Çiğdem), Ankara: Vadi Yayınları.

Örs, H. Birsen (2009). "Postmodern Dünyada İdeolojinin Dönüşümü”, İstanbul Üniversitesi Siyasal Bilgiler Fakültesi Dergisi, No:40.

Özdemir, Süleyman (2005). "Refah Devletinin Gelişme ve Bunalım Dönemlerinde İş Piyasaları", İktisat Fakültesi Mecmuası, Cilt 55, Sayı 1, 695-733.

Özsalmanlı, Ayşe Yıldız (2005), "Türkiye'de Kamu Yönetiminde Liderlik ve Lider Yöneticilik", Manas Üniversitesi Sosyal Bilimler Dergisi, Cilt 7, Sayı 13, 137-146

Rosenau, P. Marie (2004). Post-Modernizm ve Toplum Bilimleri, (Çev: Tuncay Birkan), Ankara: Bilim ve Sanat Yayınları.

Sarıbay, Ali Yaşar (2001). Postmodernite, Sivil Toplum ve İslam, İstanbul-Bursa: Alfa Yayınları.

Sütçü, Orçun (2008). Stratejik Liderlik, Yüksek Lisans Projesi, Kahramanmaraş Sütçü İmam Üniv SBE, Kahramanmaraş.

Şen, Y. Furkan (2004). Globalleşme Sürecinde Milliyetçilik Trendleri ve Ulus Devlet, Ankara: Yargı Yayınevi Yayınları.

Şentürk, Ünal (2010). Değişen Ekonomik ve Sosyal Koşulların Bir Ürünü Olarak Karakter Aşınması, Pamukkale Üniversitesi Sosyal Bilimler Enstitüsü Dergisi Sayı 7.

Şimşek, Aslı (2006). Duygusal Zekânın, Ana-Baba Tutumunun ve Doğum Sırasının Tercih Edilen Liderlik Tarzına Etkisi, Yayımlanmamış Yüksek Lisans Tezi, Ankara Üniversitesi Sosyal Bilimler Enstitüsü, Ankara.

Tengilimoğlu, Dilaver (2005). "Kamu ve Özel Sektör Örgütlerinde Liderlik Davranışı Özelliklerinin Belirlenmesine Yönelik Bir Alan Çalışması”, Elektronik Sosyal Bilimler Dergisi, 4 (14): 1-16.

Tilly, Charles (1995), Avrupa'da Devrimler: 1492-1992, (Çev. Ö. Arıkan), İstanbul: Afa Yayıncılık A.Ş.

Tümer, Günay ve Küçük, Abdurrahman (1993). Dinler Tarihi, Ankara: Ocak Yayınları.

Weber, Max (2006). Meslek Olarak Siyaset, (Çev. Afşar Timuçin-Mehmet Sert), İstanbul: Chiviyazıları Yayınevi. 
Yanıklar, Cengiz (2010). "Postmodernist Antipati: Postmodernist Sınıf(sızlık) Yaklaşımlarına Eleştirel Bir Bakış", Ankara Üniversitesi SBF Dergisi, cilt 65, Sayı 1.

Yıldız, Nuran (2012). "Yeni Zamanlar ve Yeni Liderlik Anlayışı”, Ankara Avrupa Çalışmaları Dergisi Cilt: 11, No: 1, 119-134.

Yıldız, Nuran (2013). Aşk Yüzyılı Bitti, Aşk’ta, İş’te, Siyaset’te Yeni Zamanlar, İstanbul: Doğan Kitap, 1. Baskı.

\section{İnternet Kaynakları}

Alemdar, Yusuf (2015). "ilâhî Din(ler) Mensuplarının Hayırlı Olanlarına Allah'ın Kur'an'da Öngördüğü Ortak İsim: Ümmet-i Kâime" http://eskidergi.cumhuriyet.edu.tr/makale/344.pdf. 17.12.2015.

Tümer, Günay ve Sayar, Süleyman (2015) http://www.islamansiklopedisi.info/dia/ ayrmetin. php?idno=d090316. 27.11.2015.

Scharpf, Fritz W. (1999). "The Viability of Advanced Welfare States in the International Economy: Vulnerabilities and Options", MPIfG Working Paper 99/9, September, http://www.mpifg.de/pu/ workpap/wp99-9/wp99-9.html. 19.11.2015. 